KRÉMER BALÁZS ${ }^{1}$

\title{
AZ IDŐSGONDOZÁS TÉNYEI, ELHALLGATÁSAI ÉS NARRATÍV KERETEI
}

https://doi.org/10.18030/socio.hu.2021.4.219

\section{BeVEzetés}

Már eltelt néhány év, mióta megírtam néhány cikket (Krémer 2013a, 2013b, 2013c), és nem kis részben ezek alapján, ezek tartalmát bővítve és továbbfejlesztve egy könyvet (Krémer 2015) az idősödés társadalmi problémájáról, és a rendelkezésre álló empirikus adatok alapján, az idősödés közpolitikai megoldatlanságairól. Annak, hogy a fentebb jelzett írásaim címeit kérdésként fogalmaztam meg, akkor leginkább figyelemfelkeltési funkciót szántam, és részben tisztázatlanságokra, részben a téma ellentmondására akartam ráirányítani a figyelmet: legalábbis furcsa, hogy ha az emberi élet érték, akkor a hosszabb életnek is értéket kellene tulajdonítanunk - miközben kétségbeesetten válságnak éljük meg és értékeljük azt a tényt, azt a jelenséget, hogy tovább élünk...

Tanulmányaimnak furcsa fogadtatása és utóélete lett. A hiúságomat legyezgető elismerések mellett, az idősüggyel foglalkozó szúkebb szakértői kör részéről mondandóm inkább nemtetszést, némi averziót váltott ki. Sőt, kedélyes és baráti beszélgetéseken, informálisan az idősgondozásban dolgozó kollégák (annak szoktak tekinteni, jó pár évet magam is dolgoztam a gondozási területen, egy darabig szociális otthont is igazgattam...), némi élcelődő túlzással, de „árulónak” is tekintettek amiatt, hogy kiszálltam a szakma konvencionális problémafelvetésének, koncepcióinak, narratíváinak kereteiből.²

E dolgozat legfontosabb új eredményként a szociális gondozási narrativákról szól, az értelmezés és elbeszélés kereteit, a nyelvben elrejtett kötelmeket, kötelékeket, normatív sajátosságokat elemzi. Arra igyekszem rámutatni, hogy a problémák érzékelése a gondozás szakmai-szakértői köreiben az uralkodó gondozási narratívákhoz kötött, azoknak az amúgy megérthető fogságában vergődik (Shiller 2020). Amely narratív keretekből kiszállva, ezzel a narratívával való azonosulás kötelmeit (ezzel együtt az azonos narratíva keretein belül a szakmát gyakorló közösséget) cserben hagyva, ebben az értelemben „elárulva”, az ember más tényeket másképp lát meg a gondozás problémáiként.

Írásom nem épít saját empirikus kutatásra, így eredeti felfedezésekről sem fog számot adni. Alapvetően ismert, vagy legalábbis ismerhető, az interneten elérhető (főképp az OECD, az Eurostat és a Világbank, illetve a KSH honlapjain közölt) nyilvános adatok jelentik elemzéseim empirikus hátterét. A közölt adatok számszerú elemzésén túl dolgozatomban igyekszem a közölt adatok „mögé” is bekukkantani, így kitérek az adatok keletkezéséből, forrásainak meghatározottságából, az adatközlők sajátos helyzetéből fakadó „metaadatok” ismertetésére és interpretálására, valamint a forrásokban nem közölt, illetve a különböző forrásokból összevethetetlen adatok számbavételére, ezáltal a gondozás „kvázi-intencionális”, „teszik, de nem tudják”

1 Egyetemi docens, Debreceni Egyetem, BTK, Szociológia és Szociálpolitikai Tanszék, email: kremer.balazs@arts.unideb.hu

2 A narratívák kötelmeire és az azoktól való eltávolodás cserbenhagyás, árulás kérdésére dolgozatomban a későbbiekben (a narratíva fogalmának tárgyalása és konklúzióm kapcsán) még visszatérek.

3 A fogalom Marxtól ered, de Lukács György vagy Ferge Zsuzsa is használta. A „teszik, de nem tudják” felvetésnek erős a kritikai beágyazódottsága, és a kvázi-intencionalitást úgy is lehet érteni, hogy „bár tudhatnák, de mégis úgy teszik, hogy nem akarnak tudni róla". 
tartalmaira. Törekszem arra, hogy olyan köztudott adatokat is egymás mellé illesszek, amelyeket nem szokás együtt értelmezni. Továbbá mindezen gondolati eljárásokkal a közismert adatoknak a szokásos (kritikám szerint sok szempontból a társadalmi realitásokhoz képest inadekvát) értelmezési, narratív kereteitől eltérő értelmezési, narratív lehetőségeire próbálok rámutatni.

\section{AMIT TUDUNK, MERT VAN RÓLA ADATUNK}

\subsection{Demográfia}

A dolgozatom témájához a demográfiai adatokból érdemes kiindulnunk. De, írásom témája mellett, módszertani okokból is helyes elv megpróbálni innen indítani, ha ez lehetséges. Ezek ugyanis a társadalomtudományok legmasszívabb, legmegbízhatóbb adatai. Az élet, a halál, a nemek, az életkor kérdésében nincsenek definíciós problémák, az adatokat hagyományos, beérett eljárásokkal teljes körben gyưjtik, tehát mintavételi hibák sem fordulhatnak elő. A masszív módszertani alapnak köszönhetően jók és egyértelműek a nemzetközi összehasonlítások is, amelyek, mint az összehasonlító módszerek mindig, támpontot adnak annak megítéléséhez, hogy mi a sok és mi a kevés, mi az alacsony és mi a magas.

Az összehasonlító adatok közül is a leggyakrabban használt a különböző életkorban várható élettartam. A várható élettartam adatai nagyban összefüggenek az adott ország fejlettségével és jólétével (GDP/lakosság), de ezen belül is, Magyarország vonatkozó adatai (különösen a 65 évesen várható élettartamokban) a fejlett országok körében a legrosszabbak közé számítanak (OECD - Life Expentancy 2021a, 2021b).

Alig elemzett jelenség az, hogy a nők várható élettartama mindenhol magasabb, mint a férfiaké: ez az egyike azon kevés mutatóknak, amelyekben a nők helyzete a kedvezőbb a férfiakénál. A várható élettartam az egyes emberek életkilátásait fejezi ki, de ezek alapján hasonló eltérésekre számíthatunk az idősek részarányában a társadalom egészének létszámához viszonyítva. Az ENSZ és annak Népesedési Alapja 2019es kimutatásai szerint a 65 év feletti lakosság hazai arányai közepesek, azaz, mintha eltérnének a várható élettartam rangsoraitól. A magyarázat viszonylag egyszerú: a 70 év feletti lakosság aránya a fejlett országokhoz képest kimondottan alacsony, ám az éppen 65-70 éves, nagy létszámú Ratkó-generáció „felhúzza” a 65+ éves lakosság arányát ( UN Population Fund 2019).

Amint azt az 1. ábra mutatja, nemzetközi trendekhez hasonló létszámbővülés figyelhető meg nálunk is az idősek körében (Monostori-Grestits 2018).

A demográfia, így a várható élettartam adatai körében sajátos tartalommal ruházódnak fel az iskolázottsági adatok. Nem a múveltség, a „kulturális tőke” szociológiai jelentéstartalmában szokás ezeket használni, hanem a "társadalmi státusz” nemzetközi összehasonlításban alkalmazható, leegyszerúsített „proxy-változójaként”. A társadalmi egyenlőtlenségeknek a várható élettartamra, ha úgy tetszik, a halál egyenlőtlenségeire gyakorolt hatása Magyarországon kiugróan magasnak tekinthető. Így a képzetlen és a diplomás férfiak születéskori várható élettartamának különbsége 12 év (Kovács et al. 2018). Mondhatjuk tehát azt, hogy az életkilátásokra vonatkozó kedvezőtlen adatokat a képzetlenek korai halálozása „húzza le”. 


\section{1. ábra. Az idősek létszámának növekedése Magyarországon, 1980-2021}

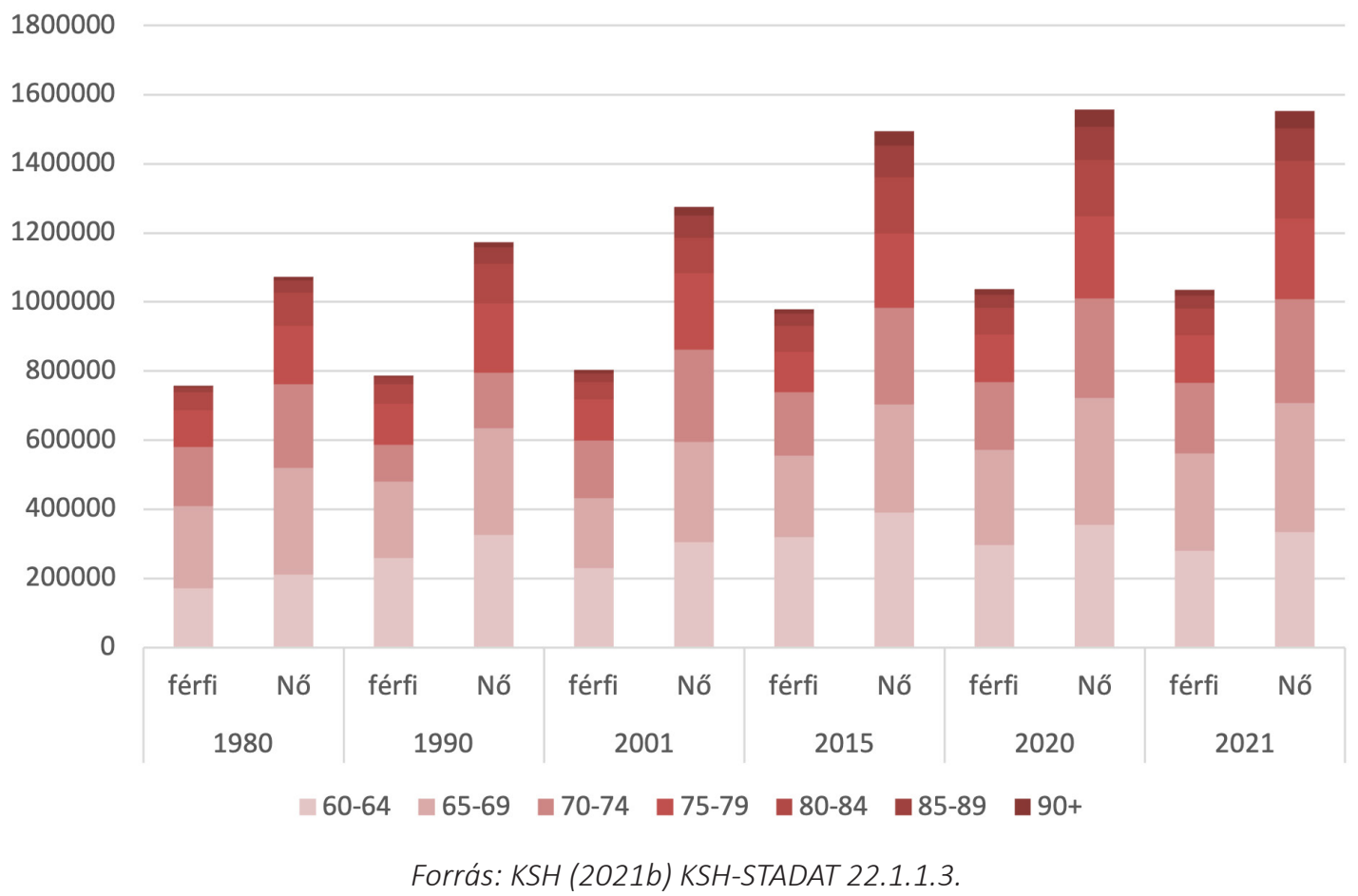

\subsection{Szubjektív értékelés a napi gondokról, az egészségi állapot súlyosságáról}

Nem tekinthető szokatlannak az, hogy az élethelyzetek sajátosságairól a nemzetközi szervezetek egységesen felvett kérdőívek - azaz, a megkérdezettek szubjektív helyzetértékelésére vonatkozó adatok alapján végeznek összehasonlító elemzéseket. Ezt a „technikát” alkalmazzák a munkaügyi (LFS), a jövedelmekre és életszínvonalra (SILC), vagy tágabban az életkörülményekre (ESS) vonatkozó elemzések, és ugyanilyen, szubjektív helyzetértékelésre alapuló reprezentatív kérdőíves adatok jelentik az egészségügyi állapotra (EHIS) vonatkozó elemzések alapját. Ez a módszer teljesen jogos és indokolt, hiszen az egyes országok jogokban, jogosultságokban, intézményes besorolásban használt kategóriái eltérőek és összehasonlíthatatlanok egymással - míg az egyforma, egységesen összeállított, mindenhol ugyanolyan kérdőívvel felvett adatok nemzetközi léptékben is összehasonlíthatók egymással.

Az egészségi állapotra irányuló adatfelvételek esetében kétféle hátránnyal is számolni kell. Torzító tényező maga a szubjektivitás. Míg az orvosoknak valamiféle objektív, sztenderd, szakszerű kategóriái vannak az egészségi állapotok leírására és minősítésére - addig a hétköznapi emberek kategóriái egyrészt nem szakszerűek, csak leegyszerűsített fogalmakkal képesek jellemezni helyzetüket; másrészt, szubjektívek abban az értelemben, hogy a „panaszkodósabbak” rosszabbnak, a „kemények” meg, akár gondjaik eltagadásával is, de jobbnak fogják bemutatni saját állapotukat.

A szubjektív önbesorolásra építő kérdőívek részben arra kérdeznek rá, hogy a megkérdezett milyennek ítéli meg egészségi problémáinak (gondjainak, betegségeinek, fogyatékosságainak stb.) súlyosságát; másrészt, a fogyatékossági kutatásokból átvéve, hogy mennyire akadályozzák az egészségi problémái mindennapi teendőinek „normál” elvégzését. A 2. ábrát a Eurostat Life expectancy by age, sex and educational attainment level (Euorostat 2020a) oldalán szereplő, teljes körűen legfrissebb (2014-es) adatok alapján állítottam össze, ezen is jól látszik, hogy a hazai lakosság egésze, és idősebb korosztályai is gyakoribb és súlyosabb egészségi problémákat élnek meg az Unió tagországainak átlagánál. 


\section{2. ábra. Egészségi problémák előfordulása és súlyossága az EU 28 átlagában és Magyarországon}

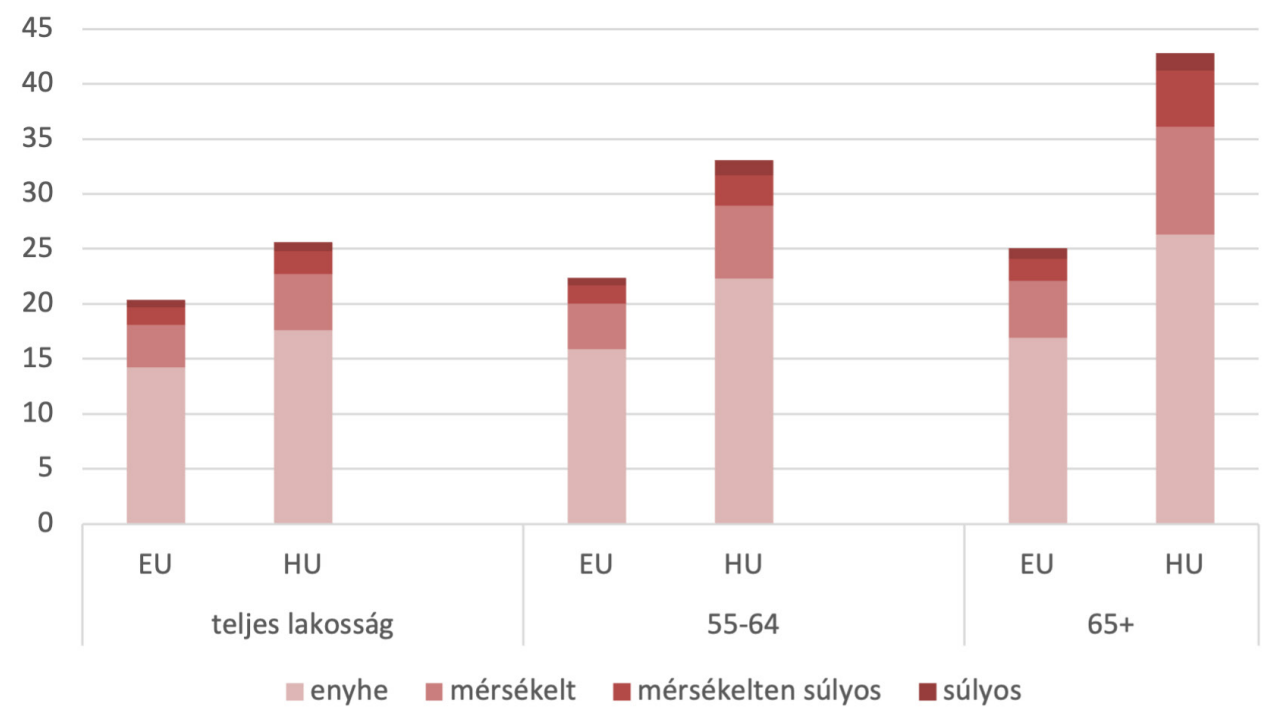

Forrás: Eurostat (2020a) Life expectancy by age, sex and educational attainment level 2014 alapján saját szerkesztés

Az „egészségi problémák” körében a hazai idősek az Unió átlagánál kisebb arányban számoltak be arról, hogy állapotuk akadályozza őket a mindennapi teendőik ellátásában, viszont, magasabb arányban számoltak be krónikus betegségük előfordulásáról. Különösen jelentős, másfélszeres az eltérés a többféle krónikus betegséggel élő idősek arányában (Eurostat 2020a). A várható élettartam iskolai végzettség szerinti egyenlőtlenségei alapján szintén várható az, hogy az egészségi állapotot az iskolai végzettség (azaz, a „társadalmi státusz") Magyarországon erőteljesebben határozza meg, mint az Unió más országaiban (3. ábra).

\section{3. ábra. Egészségi problémák előfordulása és súlyossága a hazai 16+ éves lakosság körében}

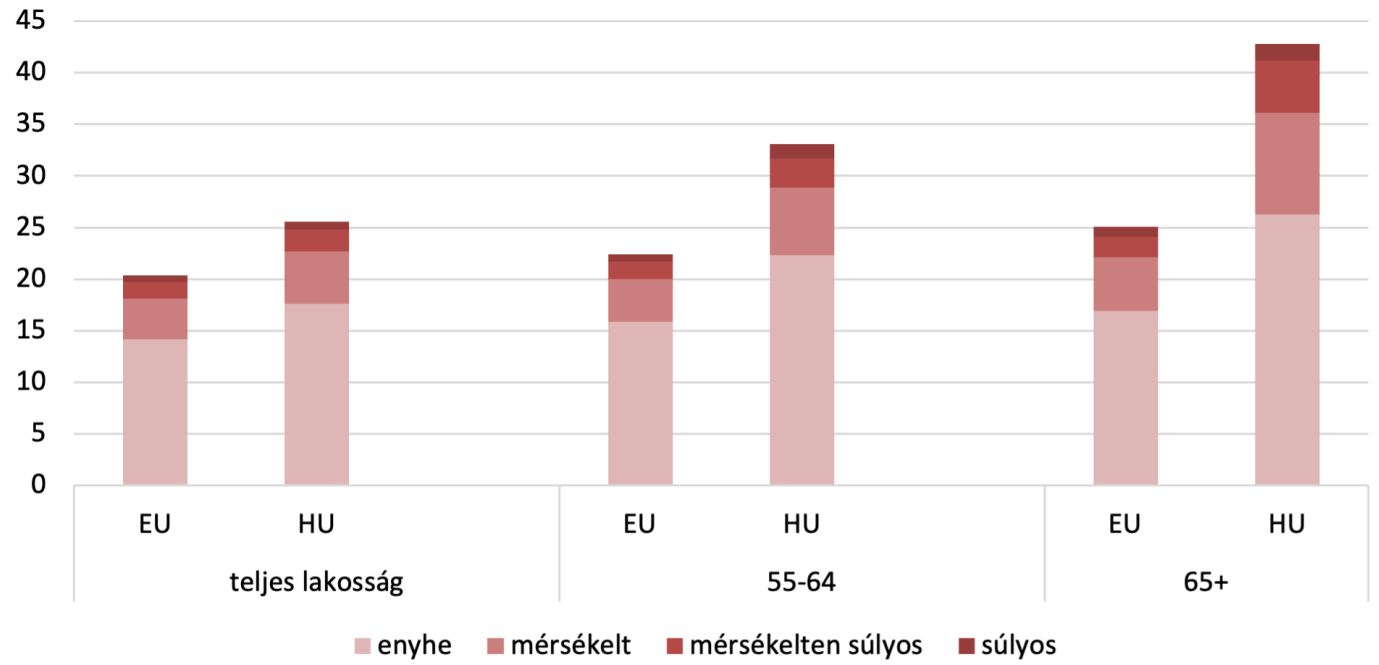

Forrás: Eurostat (2020a) Life expectancy by age, sex and educational attainment level 2014 alapján saját szerkesztés

Két jelenség azonban nem jelezhető előre a korábbi adatokból. Az egyik az, hogy noha a nők „objektív” halálozási adatai egyértelmúen jobbak a férfiakénál, aközben a saját egészségi állapotuk "szubjektív” megítéléseiben a mutatóik rosszabbak, mint a férfiakéi. Lehet azt mondani, hogy a nők „inkább panaszkodósak” a saját egészségükről, mint a férfiak, de talán jobban fedi az igazságot az, hogy a nők (ha úgy tetszik, nemi szerepeikből következően is) jobban odafigyelnek testük-lelkük egészségére, és pontosabban, jobban érzékelik a fellépő problémáikat, mint a férfiak. 
Van azonban egy másik, talán még inkább elgondolkodtató jelenség az érzékelt gondok előfordulásában és súlyosságában. Nem túl elegáns, de tán érzékletes az az általam alkalmazott grafikonszerkesztési módszer (4. ábra), hogy mind a 65 feletti férfiak, mind a 65 feletti nők oszlopai mellé odatettem az 55-64 éves alacsony végzettségú korosztályok oszlopait, amelyek azt mutatják, hogy már az alacsonyabb végzettségú fiatalabb nők egészségi állapota is rosszabb, mint az idősebb, ám képzettebb nőké. Ám az igazán megdöbbentő adat az, hogy az 55-64 éves alacsony végzettségű férfiak egészségi mutatói még annál is rosszabbak, mint a hasonló státuszú 65+ éves férfiak adatai. A halálozási adatokkal összevetve egyetlen spekulatív magyarázatot találtam e jelenségre: az 55-64 éves alacsony végzettségű férfiaknak egy jelentős része annyira feléli az egészségét, hogy ebbe rövid időn belül bele is hal; míg az a részük, aki megéri a 65. életévét, az jobb egészségi állapotnak örvendhet további (nem túl hosszú) életében is.

\section{4. ábra. Egészségi problémák elöfordulása és súlyossága a hazai 65+ éves (valamint a képzetlen 55-64 éves) lakosság körében, iskolai végzettség szerint}

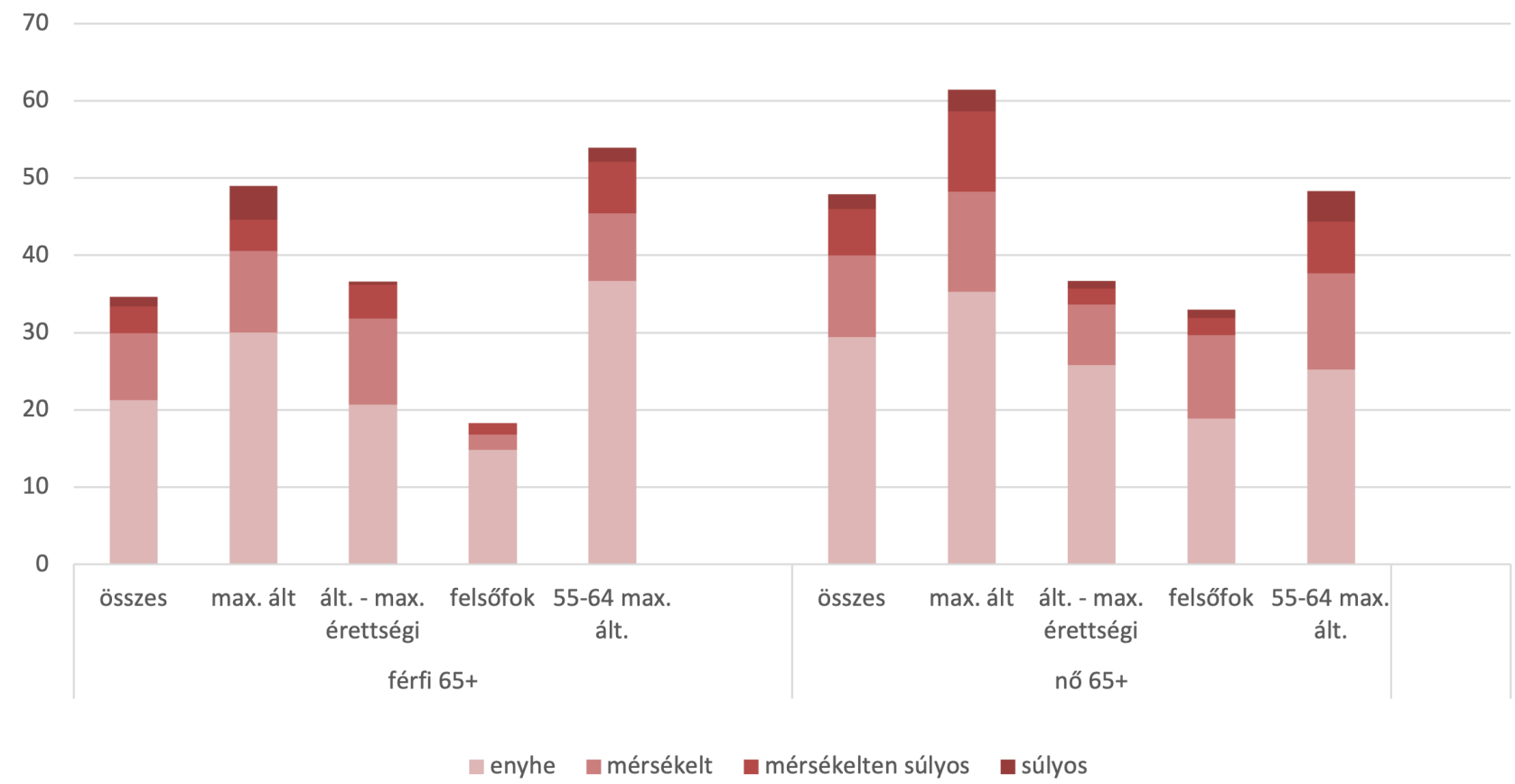

Forrás: Eurostat (2020a) Life expectancy by age, sex and educational attainment level 2014 alapján saját szerkesztés

Noha szeretnénk abban a banalitásban hinni, hogy valaki minél magasabb életkort él meg, annál idősebb ez az evidencia azonban felborul akkor, ha az idősödést az egészségnek a halál előtti leépüléseként, feléléseként akarjuk értelmezni. Különböző társadalmi helyzetű emberek különböző életkorukra élik fel az egészségüket, különböző életkorokra gyűlnek fel a betegségeik, bajaik, fogyatékosságaik és egészségi problémáik - azaz, különböző életkorukra öregednek meg, válnak időssé.

Az objektív (halálozási) női előnyök ellenére, a nők gyakrabban panaszkodnak súlyos akadályozottságukra. De, a nemi szerepekről korábban elmondottakat megerősítendő, itt is érdemes felhívnom a figyelmet arra, hogy amikor a férfiak sokkal kevésbé panaszkodnak akára testközeli, akár a háztartásiteendőik akadályozottságára, mint a nők - akkor ez nyilvánvalóan nem jelentheti azt, hogy ők a nőknél ügyesebben, rafináltabban, jobban képesek ellátni ugyanazokat a teendőket. Sokkal inkább azt jelenti a súlyos akadályozottság nemek közötti megoszlása, hogy a férfiak eddig sem nagyon törődtek egészségük, testük-lelkük gondozásával, orvos felkeresésével (Oksuzyan et al. 2019, Gil-Lacruz-Gil-Lacruz 2010), no pláne a háztartási teendők ellátásával (OECD Time 
Use 2019), így az e területen mutatkozó gondokat sem élik meg különösebben súlyos akadályozottságként, korlátozottságként. És ismét, a férfiak körében könnyen megeshet az, hogy például a testük elhanyagolása összefügg mind a súlyos egészségi problémáik gyakoriságával, mind a rosszabb halálozási mutatóikkal is: nem veszik észre időben (vagy egyáltalán) a problémákat, ami súlyos következményekhez vezet. A férfiak és nők közötti test- és egészégtudatosságban mutatkozó eltérésnek a fentiekhez hasonló hatását sejthetjük abban is, hogy az egészségben leélt életévekben a nők „előnye” kisebb, mint a várható élettartamban - azaz, mintha előbb érzékelnék a betegségeiket, és előbb jelentkeznének orvosnál is a panaszaikkal, mint a férfiak

\subsection{Gondozás, gondozottak gondozók - „hivatalos” formákban}

A gondozási adatok metatartalmainak megfejtése a korábbiaknál nehezebb feladat.

Már az ápolás fogalma sem definiálható szabatosan, de, még mindig ezerszer jobban, mint a gondozás fogalma (azápolásnak például lépésről lépésre részletezett folyamatszabályozásai, protokolljai vannak-hasonlók a gondozásban nem léteznek). Ebben nyilván szerepet játszik az idő és a hagyomány faktora: intézményesen szabályozott, iskolában tanított szakmaként az (egészségügyi) ápolás sokkal régebbi, jobban beérett foglalkozás, mint a szociális gondozás ${ }^{4}$ - amelyről nem tudjuk, hogy specifikus részfolyamataiban mit is jelent. Nincsen ebben semmi meglepő: ha nem tudjuk azt, hogy kik, milyen társadalmi helyzetben, milyen életkorban válnak „időssé”, akkor azt sem tudhatjuk, hogy e jelentős eltérések mellett kinek milyen gondokat okoz az idősödése.

A gondozásról szóló ismereteink forrásai maguk a gondozás intézményei (intézményesült formái). ${ }^{5}$ (A gondozás összehasonlítható nemzetközi adatait lásd: OECD 2018, OECD 2020b, illetve Eurostat 2020b.) Ez önmagában hordoz némi torzító hatást: az intézmények a maguk adatszolgáltatásával igyekeznek megfelelni a jogi ${ }^{6}$ és egyéb, például szakmai, etikai normáknak, maga az adatszolgáltatás nemcsak információt ad, hanem „önlegitimálásként” is szolgálhat. Az intézményesült, tehát az intézmények adminisztrációjából származó adatoknak azonban automatikusan van egy olyan sajátossága, amelynek az értelmezése túlmutat a statisztikai adatok szakszerű használatán. Az adminisztratív adatszolgáltatás csak olyan adatokra vonatkozhat, amelyek rögzítésére, nyilvántartására, „elkönyvelésére” jogszabály vagy bürokratikus előírás kötelezi a gondozás intézményeit. Ilyen adatoknak muszáj megszületniük az intézmények múködése során - más adatok kötelező és általános érvénnyel nem állnak rendelkezésre. Ez - az adatok tartalmának korlátozottsága mellett - azonban még egy fontos szervezetszociológiai sajátosságra is rámutat: az adminisztratív intézményi adatok nem lehetnek jobbak - mint maga az adminisztráció, a gondozás igazgatása. Amilyen adatokra a rendszer igazgatásához

4 Magyarországon a forradalom és szabadságharc idején Kossuth Zsuzsa vezetésével ápolónői szolgálat múködött, a modern ápolónőképzés már a XIX. században elindult. Ez az ápolói szakma a későbbiekben számos szociális elemmel kiegészült (PI. a zöldkeresztes nővérek már 1927-től a mai védőnői munkához hasonló feladatokat láttak el, a bentlakásos idősotthonokban a gondozási feladatokat ma is jelentős arányban ápolónői végzettséggel látják el stb.), de az ápolástól elkülönült szociális gondozói szakmára csak az elmúlt évtizedekben kezdtek el képezni.

5 Bizonyára lehetne markánsabban is megkülönböztetni azt a két különböző fogalmat, amelyet én csak egy nyelvi nüánsszal tudok megtenni. Az antropológiából átvett szóval, intézményesült gondozásnak azokat a tevékenységeket fogom nevezni, amelyeket gondozásként szokásszerúen, rutinszerűen, jellemzően írott szabályokat (jogokat, jogosultságokat, intézményi statútumokat, munkaköri leírásokat stb.) követve végeznek. Ezzel szemben, intézményi gondozásnak (institutional) a bentlakásos, „intézet” jellegú formákat hívom.

6 A legfontosabb szakmai jogszabály az igen gyakran módosított, eredetileg 1993-ban hatályba lépett Szociális Törvény, illetve a hozzá csatlakozó, a múködés feltételeit szabályozó 1/2000. számú kormányrendelet. 
szükség van, azt lehet is, kötelező is szolgáltatni,7 arról elérhetők az adatok - és az is igaz, hogy a rendszert azon ismeretek és információk alapján igazgatják, irányítják és ellenőrzik, amelyek rendelkezésre állnak.

Mindez magyarázza és indokolja azt a korlátozottságot, amely egyfelól következik a gondozás tartalmáról való nem-tudásból; másfelől, különösen a hazai államigazgatásnak amúgy is régi bevált gyakorlatának megfelelően, a rendelkezésre álló adatok szinte kizárólag input jellegű mutatók. Mindenekelőtt az, hogy mennyi pénz jut az intézményekhez, és alapvetően a pénz felhasználását milyen egyéb mutatók támasztják alá: mekkora és milyen összetételű stábot foglalkoztatnak, mekkora az ellátotti létszám, a bejövő és kimenő ügyfélforgalom, és ezekhez képest mellékesként kezelve, milyenek az elhelyezési feltételek és milyen dologi jellegű ráfordítások keletkeznek az így értelmezett, intézményesült gondozás során. Output és outcome jellegú adatok a gondozás során elvégzett munka részletezett tartalmáról, mennyiségéről, minőségéről, hatásáról vagy kimeneteléről stb. alig állnak rendelkezésre.

\section{AZ A MÉG TÖBB, AMIT NEM TUDUNK (PEDIG AKÁR TUDHATNÁNK IS...)}

Az alábbiakban megpróbálom összeszedni azt, amit nem tudunk az idősgondozásról, jelezve azt is, hogy számos nem ismert körülményről nyilvánvalóan léteznek adatok vagy igen könnyű lenne beszerezni azokat ám, ezeket a gondozás igazgatási rendszere mintha érdektelennek tekintené.

\section{A gondozottak társadalmi helyzete, státusza}

A demográfiai és a szubjektív helyzetértékelésre vonatkozó adatok is (afféle proxy státusz-változóként) rögzítik és bontják az adataikat iskolai végzettség szerint - ám a gondozottak iskolai végzettségéről akkor sincs tudásunk, ha ezeket az adatokat könnyű lenne beszerezni. Nem tudunk semmit a gondozottak jövedelmi helyzetéről - miközben tudjuk azt, hogy az általuk kötelezően befizetendő térítési díjak kalkulálásához az intézményeknél biztosan ott vannak a jövedelmekre vonatkozó adatok. Ugyancsak korlátozottan ismerjük a gondozottak települési és lakásadatait, így például nem tudjuk a kül- és belterületen élők arányát. Az látszik az adatokból, hogy azokon a településtípusokon, ahol magasabb az idősek aránya (Budapest és az aprófalvak), ott magasabb a házi gondozásban részesülő idősek aránya is, de ezekben az esetekben sem ismerjük sem a lakott lakások sajátosságait, sem „urbanisztikai” jellemzőit (van-e közlekedés, milyen messze van a bolt, a patika stb.). Arról semmit nem tudunk, hogy mely településen, milyen lakáskörülmények között éltek az idős emberek, mielőtt bentlakásos intézményben nyertek volna elhelyezést.

\section{A gondozottak életkilátásai és halálozása}

Bár ismerjük a gondozottak életkori megoszlását, de nem ismerjük halálozási adataikat, és így még becsléseket sem tudunk tenni arra, hogy vajon a gondozottak kedvezőbb életkilátásokkal jellemezhetők-e, mint a hasonló helyzetű, hasonló státuszú, ám gondozásban nem részesülő kortársaik; netán, hogy a gondozás hozzájárul-e a hosszabb élet kilátásaihoz? (A demográfiai adatok alapján persze az is igaz, hogy az iskolai végzettség nem-tudása nélkül a gondozásnak az életkilátásokra gyakorolt hatása sem lenne elemezhető.)

\section{A gondozásba vétel egészségi okai, a gondozottak egészségi állapota}

Bár az igénylés benyújtásához szükséges a háziorvos szakvéleménye, de nem ismerjük azt, hogy a gondozottak milyen arányban, milyen súlyossággal és milyen jellegű „időskori fogyatékosságban” (látás-,

7 Magyarországon a közintézmények kötelező adatszolgáltatása részben szakhatósági (ÁNTSZ, Túzoltóság stb.) adatszolgáltatás, jelentősebb részben a pénzköltésükhöz, gazdálkodásukhoz kapcsolódó mérlegbeszámolók, illetve az ezekkel számos ponton összeérő, a KSH által végzett kötelező adatszolgáltatási rendszer (OSAP). Ezen adatforrások jelentik a statisztikai feldolgozás alapját. 
hallás-, mozgáskárosodás stb.) szenvednek, milyen szellemi állapotban, milyen krónikus betegségekkel kerülnek gondozásba, vagy hogy milyen a már gondozásba vettek épsége-egészsége, vagy annak károsodása.

A nem-tudások egy jelentős része nem „magyar átok”, hanem az egész világra jellemző (a bizonytalanságokról gazdag hivatkozásjegyzékkel áttekintést nyújt: Oksavik et al. 2021, illetve Lo 2020). Keveset tudunk az időskorban gyakori krónikus betegségekről (Alzheimer, Parkinson, demencia stb.), és nemhogy a terápiák kiforratlanok, de még a betegségek korai diagnosztizálására is kis eséllyel képes a mai orvostudomány. Bár igaz az, hogy az elmúlt években forradalmi változások ${ }^{8}$ zajlottak le nemcsak az akut ellátásokban (pl. kardiovaszkuláris, daganatos terápiák), hanem az idősek krónikus terápiáiban is, amelyek révén nem csupán átlagosan tovább élnek az idősek, de egészségesebben és jobban is élnek tovább.

Az egészségi állapotokról való nem-tudás még a súlyosan leépült, folyamatosan ápolásra/gondozásra szoruló idősek esetében is megkülönböztethetetlenné teszi azt, hogy ugyanolyan állapotban ki és miért kerül bármilyen gondozásba, és akik bekerülnek, azok miért épp kórházi krónikus osztályra vagy szociális gondozási intézménybe. (Mára, a pandémia és a kórházi ágyszámcsökkentési tervek nyilvánosságra szivárgása nyomán ez a kérdés leegyszerűsödni látszik: a krónikus ágyak és osztályok megszűnőben vannak.)

\section{A gondozás tartalma}

Hazai viszonyaink között a legégetőbb gondnak azonban nem az új terápiák elterjedésével kapcsolatos ismerethiányt, hanem a "hagyományos” gondozás tartalmának nem-ismeretét tartom. Bár tudjuk azt, hogy a gondozásként elkönyvelt és elszámolt segítés igen gyakran kimerül a gondozottal való beszélgetésben, egyszerúbb háztartási munkákban való segítségnyújtásban, ${ }^{9}$ de nem tudjuk azt, hogy vajon mekkora arányban merül ki a gondozás ezekkel a szakképzettséget nem igénylő, „gyenge segítségekkel”.

Semmilyen gondozási formában nem tudjuk azt, hogy a gondozás mennyiben foglalja magában a gondozott egészségi állapotának (vérnyomásának, emésztésének, látás-, hallás- és mozgásképességének stb.) kontrollját, ennek megfelelően azt sem igazán, hogy mi a gondozási teendő akkor, ha mégis kiderülne az egészségromlás. Ennél még kevésbé tudjuk azt, hogy ki vágja a gondozottak haját, a körmét (amely állapot jelentősen befolyásolja a gondozott mozgás- vagy kapcsolatképességét) és pláne nem azt, hogy vajon a gondozó megteszi-e ezt akkor, ha a fodrász vagy a pedikűrös nem elérhető, vagy ha a gondozott nem tudja megfizetni azokat. A hajápolás vagy a körömvágás inkább csak példa, számos más olyan körülmény és állapot is meghatározható, amely hozzátartozik, illetve hozzátartozna a normális és kapcsolatban kellően gazdag élet fenntartásához, de nem tudjuk, hogy beletartozik-e a gondozásba.

Nem tudjuk azt sem, hogy tartanak-e kapcsolatot (akár személyesen, akár telefon, internet, más technika közvetítésével) a gondozottak a családtagjaikkal, barátaikkal, vagy azt, hogy kimozdulnak-e egyáltalán lakhelyükről - akár a szabad levegőn tartózkodás, akár mások felkeresése érdekében. Így persze

8 A forradalminak minősíthető fejlődés két legjelentősebb területe a mozgáskorlátozottság és a mentális problémák kezelésében érzékelhető. Javult és bővült a gyógyszeres (pl. porcerősítők) és a fizikoterápiás beavatkozások eredményessége, és különösen, robbanásszerűen fejlődtek a mútéti technikák (pl. ízületi protézisek). A mentális problémák esetében a gyógyszeres terápiák fejlődtek robbanásszerúen, különösen némely pszichiátriai betegség (epilepszia, skizofrénia, depresszió különféle válfajainak) tünetmentesítésében, illetve az agyi vérellátást korlátozó meszesedés gyógyításában. Mindehhez még hozzá kell vennünk a műszaki technika fejlődésének átgyưrűzését az idősellátásba, így az optikai lencsék és a hallásjavító készülékek minőségének javulását, vagy akár az internetes eszközök alkalmazási lehetőségeinek fejlődését, akár a személyes kapcsolatok bővítésének lehetőségében (Skype és akár gyógytorna és pszichoterápia levezénylése ilyen eszközökön), illetve a távfelügyeleti, egészségmonitorozási lehetőségek bővülésében.

9 Sőt, a nemzetközi gyakorlattal szemben (ahol például a „Meals on Wheels” szolgáltatást nem tekintik gondozásnak) a hazai gyakorlatban gyakran a házhoz kiszállított szociális étkeztetést is „házi gondozásként” könyvelik el. 
azt sem tudjuk, hogy vajon a gondozás tartalmilag magába foglalja-e a kimozdulás segítését, szervezését, előmozdítását, avagy sem.

A gondozási adatokból nem ismerhetjük meg a gondozottak „előéletét”, azt, hogy mi is lenne az a megszokottan normalizált és integrált élet, melynek a támogatása lenne a gondozás célja. Ez persze igencsak nehéz adatfelvételi feladat lenne, de az ennél egyszerúbben megismerhető adatok is hiányoznak a gondozásról való ismereteinkben.

\section{Kiket, miért és hogyan is gondozunk?}

Pusztán a számokat nézve (1. táblázat) az alábbiakat látjuk arról, hogy mekkora arányban gondozzuk az idős embereket.

\section{1. táblázat. Az ellátott gondozottak létszámának és arányának változása}

\begin{tabular}{|c|c|c|c|c|}
\hline \multicolumn{4}{|l|}{ Bentlakásos - minden, ami nem (akut) kórház } & \multirow[b]{2}{*}{2018} \\
\hline & 2005 & 2010 & 2015 & \\
\hline Teljes gondozott létszám & 73730 & 79053 & 80822 & 80211 \\
\hline $0-65$ & 28777 & 29439 & 28234 & 24527 \\
\hline $65+$ & 44953 & 49614 & 52588 & 55684 \\
\hline $80+$ & 21421 & 26885 & 30416 & 32429 \\
\hline \multicolumn{5}{|l|}{$\begin{array}{l}\% \text { - a jelzett korosztály létszámának } \\
\text { arányában }\end{array}$} \\
\hline & 2005 & 2010 & 2015 & 2018 \\
\hline Gondozottak aránya a teljes népességben (\%) & 0,7 & 0,8 & 0,8 & 0,8 \\
\hline $0-65$ & 0,3 & 0,3 & 0,3 & 0,2 \\
\hline $65+$ & 2,9 & 3 & 3 & 3 \\
\hline $80+$ & 6,3 & 6,8 & 7,3 & 7,6 \\
\hline \multicolumn{5}{|l|}{ Otthoni ellátások } \\
\hline Teljes létszám & 142690 & 184382 & 258177 & 215613 \\
\hline $0-65$ & 39874 & 57202 & 70721 & 51492 \\
\hline $65+$ & 102816 & 127180 & 187456 & 164121 \\
\hline $80+$ & 32299 & 43644 & 63090 & 59620 \\
\hline \multicolumn{5}{|l|}{$\begin{array}{l}\text { \%-a jelzett korosztály létszámának } \\
\text { arányában }\end{array}$} \\
\hline Gondozottak aránya a teljes népességben (\%) & 1,4 & 1,8 & 2,6 & 2,2 \\
\hline $0-65$ & 0,4 & 0,6 & 0,7 & 0,5 \\
\hline $65+$ & 6,5 & 7,6 & 10,8 & 8,9 \\
\hline $80+$ & 9,6 & 11,1 & 15,3 & 13,9 \\
\hline
\end{tabular}

Forrás: OECD, 2021c Long-Term Care Resources and Utilisation: Long-term care recipients alapján saját szerkesztés

Az idősorok, bár némi ingadozással, de a gondozott idősek létszámában növekményt jeleznek, viszont az idős korosztályok teljes létszámához viszonyítva (a házi gondozásban részesülő 80 évnél idősebbek közel másfélszeresére való növekedésén túl) csökkenő arányt mutatnak.

Van azonban ennél egy súlyosabb, a tábláról kiolvasható probléma. Azt látjuk, hogy a 65+ éves lakosság 3\%-át gondozzák bentlakásos intézményben, házi gondozást kap 8,9\%-uk, azaz, összesen a 65+ korú lakosság kevesebb mint 12\%-a részesül bármiféle gondozásban. Ugyanezek az arányok a 80+ éves lakosság esetében: 7,6\%-uk bentlakásos, 13,9\%-uk házi gondozott, összesen a 80+ korú lakosság 21,5\%-a kap bármiféle gondozást. 
- Amit, ha "megfordítunk”, akkor azt kapjuk, hogy a 65+ éves lakosság 88\%-a, a 80+ éves lakosság 78,5\%-a semmiféle gondozásban nem részesül. Ha ezek mellé illesztjük a nem-tudások és az elhallgatások hevenyészett leltárát, akkor egyszerüen képtelenek vagyunk válaszolni arra, hogy vajon milyen szempontok alapján választódik ki a 65 év feletti lakosságnak az a 12,5\%-a, akik bármilyen gondozásban részesülnek.

Összefoglalva: nemcsak azt nem tudjuk, hogy konkrétan milyen segítségéket jelent a gondozás, de még azt sem, hogy kiket miért is gondoz a szociális gondozás intézményrendszere.

\section{AMI AZ ISMERT ADATOKBÓL A NEM-TUDÁS FÁTYLA ALÓL MÉGIS FELSEJLIK}

Olykor lehet, hogy azért nem tudunk valamiről, mert olyan nincs is, és ezek a nem-tudások a leginkább zavarba ejtőek. ${ }^{10} \mathrm{~A}$ fő kérdés a nem-tudások boncolgatásában az okok kérdése: vajon mi az oka, ki miért is igényli a gondozást, és miért is gondozzák olykor némelyiküket? Amely kérdésre nyilvánvalóan nem lehet egységes, „egyetlen” választ adni. Ki ezért, ki azért igényli a gondozást, kit ezért, kit azért meg olykor „gondozásba vesznek”. Mert ami felsejlik, az éppen ez: az átlagidősre szabott átlaggondozás egyáltalán nem biztos, hogy hathatósan segíti a gondozottakat a jobb élethez.

\section{A „szegényházi gondozás”}

All. világháború után létrejött „szociális” otthonok majdhogynem szegényházjellegú szociális intézmények voltak. Azoknak a megélhetés nélkül maradt idős parasztembereknek és-asszonyoknak az ellátását tekintették feladatuknak, akik a'70-es évek közepéig nem voltak részesei a társadalombiztosításnak, idős korukra semmilyen jövedelemforrásuk nem maradt, ha már nem tudták a nehéz paraszti munkákat elvégezni, nem tudták magukat eltartani. Ez a "szegényházi” hagyomány még a '90-es évek elején is oly erős volt, hogy az intézményeknek kötelességük volt zsebpénzt is biztosítaniuk a jövedelem nélküli lakóiknak.

Mára ez a hagyomány részben átalakult, az idősek körében a szegénységi ráta az elmúlt évtizedekben folyamatosan kisebb volt, mint az aktív korosztályokéban,, ${ }^{11}$ és különösen, mint a gyerekek-fiatalok körében. Sőt, azt is tudhatjuk, hogy az idősek jelentik azt a korcsoportot, akik körében a jövedelmük arányában a legmagasabb a takarékoskodás, nem élik fel folyó jövedelmüket a rendszeres fogyasztásra, amitől az idősek szegényebbnek élik meg életüket annál, mint amit a jövedelmük megengedne. E mögött társadalmi szokásrendeket nevezhetünk meg egyik okként: a nagymamáknak jelentős az unokákba való „beruházása” (tanévkezdésre, érettségi és diplomaajándékra stb.), és szintén spórolnak a később megnövekedő egészségi kiadásaikra (és az azokkal együtt növekvő hálapénz kifizetésére), olykor a tisztes temetésükre. Ám e takarékoskodási szokásukat mintha túl későn kezdenék, nincsenek korábbi életükben felhalmozott tartalékaik - bár hiteltartozásaik sincsenek. Ezt igazolják a Nemzeti Banknak az EU koordinálása mellett elvégzett kutatásai (MNB 2017). Az adatok azt mutatják, hogy az idősebb (különösen a 75+ éves) generációk vagyona, a lakás és egyéb ingó- és ingatlanvagyonhoz képest - különösen pénzügyi megtakarításaik - töredékét sem teszik ki az aktív generációkénak. A korcsoportok vagyonának megoszlása minden korosztályban igen jelentős, a jövedelmeket lényegesen meghaladó egyenlőtlenséget mutat, s így a legmagasabb jövedelmú időseket leszámítva az időseknek alig vannak pénzügyi tartalékai.

10 Hogy például azért nem tudunk az akár meggyúlt és benőtt lábkörmök levágásáról, mert azt (ha nem jön pedikűrös az otthonba vagy nincsen a gondozottnak pénze megfizetni) nem is szokás, vagy csak nagyon ritkán szokás levágni, és sok idős ember mozgáskorlátozottságát épp a körmeinek állapota okozza.

112010 előtt az idősek körében a szegénységi küszöb alatt élők aránya az országos átlag felét, a 6\%-ot sem érte el. Mára az idősek körében a szegények aránya több mint duplájára nőtt, alig marad el az országos átlag 15\%-ától. Bár új adatokat nem ismerek, de az is szinte biztos, hogy a nyugdijak egyenlőtlensége - mely korábban is magasabb volt, mint a béreké - még tovább nőtt. 
Az egyedül maradó, egyszemélyes háztartásban élő, főképp özvegyen maradt idős nők számára az egy főre jutó lakásköltségek is magasabbak, ami tovább csökkenti az egyéb fogyasztásra fordítható jövedelmüket. Mindezt tetézi az, hogy a nyugdíjak (folyó bevételeik) reálértéke folyamatosan romlik, hogy nincsenek megtakarításaik, tartalékaik, a lakásuk fenntartásával járó váratlan (és jellemzően nagyobb), növekvő összegú kiadásokat a csökkenő értékű jövedelmükből (nyugdíjukból) és csekély megtakarításukból nem tudják, nem tudnák fedezni. Nem túl emelkedett ennek belátása, de vannak idős emberek, akiket egyszerúen azért kell gondozni, mert szegények. Mert nincsen pénzük élelmiszerre (és akkor „szociális étkezést” kaphatnak), nincsen pénzük rezsire és a lakásuk fenntartására - és a „koszt és kvártély” biztonsága teszi vonzóvá számukra a szociális intézmények „gondozását” igényelni.

\section{A magány}

Figyelmet érdemel az, hogy a gondozottak körében a nők részaránya magasabb, mint az idős korosztályokon belüli arányuk (2. táblázat). Ez az aránytöbblet különösen szembeötlő annak tükrében, hogy ezekben a korosztályokban a nők egészségesebbek, hosszabb életre van kilátásuk, mint a férfiaknak.

\section{2. táblázat: A nök aránya a jelzett korosztályból a gondozásban részesülök között}

\begin{tabular}{|l|c|c|}
\hline & 2005 & 2018 \\
\hline \multicolumn{3}{|c|}{ intézményi ellátásban } \\
\hline $65+$ & 72,8 & 74,2 \\
\hline $80+$ & 81,1 & 82,9 \\
\hline \multicolumn{3}{|c|}{ otthoni ellátásban } \\
\hline $65+$ & 71,0 & 74,0 \\
\hline $80+$ & 73,9 & 78,5 \\
\hline
\end{tabular}

Forrás: OECD 2021c alapján - Saját összeállitás

Megeshet, hogy erre az arányeltolódásra jó magyarázat az, hogy noha az „objektív állapotuk” nem indokolná a nők ilyen arányú többségét a gondozottak között, de az a tény, hogy rosszabbnak élik meg egészségi állapotuk vagy akadályozottságuk romlását, a nők nagyobb arányban „igénylik” a gondozást, és emiatt jutnak nagyobb arányban hozzá. Ám az is lehet, hogy a nők magasabb arányát a gondozottak között épp a jobb életkilátásaik okozzák. Hogy amíg együtt élnek, addig gondozzák partnerüket, ám azok halála után, túlélve partnereiket - magányossá válnak, nagyobb bizonytalanságban és több szorongással élik egyedül életüket. ${ }^{12}$ Hogy a magány indokolja magasabb arányú jelenlétüket a gondozottak között. Ha ez lenne a helyzet, akkor az eléggé súlyos probléma: a magány ellenszerének nem is túl jó, de bizonyosan pazarlóan túl költséges az intézményes gondozás „gyógyszerével” élni, ennél sokkal takarékosabban sokkal jobb, az önálló életvitelt erősítő „közösségi” ellenszereket is lehetne találni a magány oldására. A magány (vele együtt a szorongás, a depresszió) problematika jelenlétét erősíti az idősek (korábban jelzett) anyagi helyzete. A megtakarítások hiánya tovább rontja a biztonságérzetet, fokozza a magány okozta félelmeket és szorongásokat, további indítékot jelent a gondozásba való „bemenekülésre”, ha ez lehetséges.

\section{Ápolási szükséglet}

Egészen más jellegű és minden bizonnyal az időskorú lakosság egészen más csoportjait érintő szükségletekre és igényekre következtethetünk akkor, ha a tartós „ápolás és gondozás”, tehát a szociális

12 A legutóbbi (2011) népszámlálás adatai szerint 15808260 év feletti férfi élt egyedül háztartásában, míg az egyfős háztartásban élő 60 év feletti nők száma 534101 fő volt. Lásd: http://www.ksh.hu/nepszamlalas/tablak_haztartas 


\section{5. ábra: A tartós gondozás (LTC) GDP-arányos ráforditásai néhány EU tagállamban}

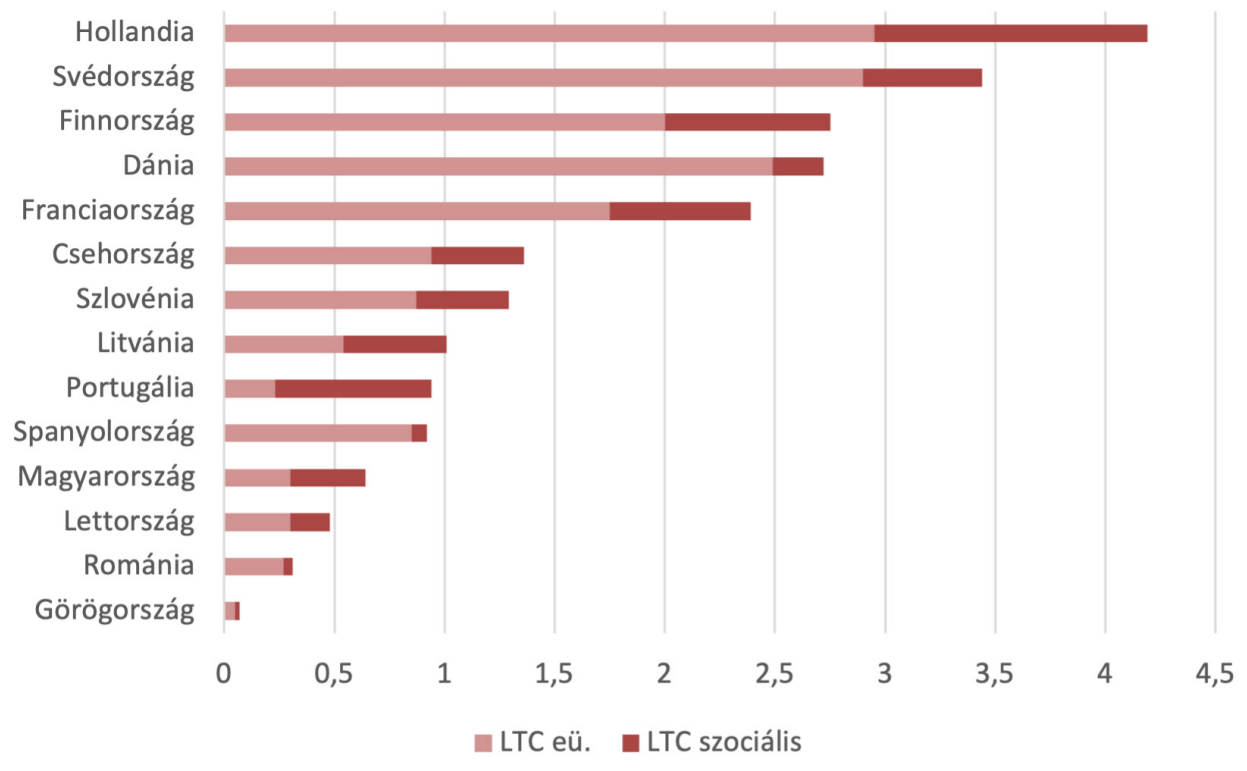

Forrás: Eurostat 2021a.

gondozás és a krónikus egészségügyi ellátás viszonyát vizsgáljuk. ${ }^{13}$ Magyarországon a szociális és egészségügyi tartós gondozás (Long Term Care - LTC, Eurostat 2021b, OECD 2021d, OECD2020c) GDP-arányos ráfordítása nemzetközi összehasonlításban közepesnek, az alacsonyabb fejlettségű tagállamok körében átlagosnak minősíthető. Ha kizárólag a tartós egészségügyi ápolás-gondozás GDP-arányos ráfordításait nézzük, akkor ebben a rangsorban Magyarország lényegesen rosszabb pozícióban található (5. ábra). A tartós otthoni ápolás ráfordításaira az Uniós országok GDP-arányosan, átlagosan ötvenszeresét költik a hazai kiadásoknak. Másképp kifejezve, míg az Unió egészében GDP-arányosan a hazai arány nagyjából ötszörösét költik átlagosan a szociális és egészségügyi tartós gondozás együttes kiadásaira, addig ugyanez a szorzó csak az egészségügyön belüli tartós ápolás GDP-arányos ráfordításaiban ennél lényegesen nagyobb. (Valószínű, hogy a COVID-19 járvány nyomán e lemaradásunk még inkább nőtt azzal, hogy a fertőzött betegek számára először épp a krónikus osztályokat ürítették ki, ott szüntettek meg további ágyakat.)

Az egészségügyi és szociális férőhelyek közötti átrendeződésnek, a krónikus ápolási ágyak alacsony számának (KSH 2020n KSH2021a) bizonyosan komoly hatása volt nemcsak általában az egészségügyi kiadások GDP-arányos csökkenésére, hanem a szociális és egészségügyi foglalkoztatottak számában az elmúlt évtizedben beállt jelentős fordulatára is, ahogy ez a 6. ábrán is jól látható.

Eléggé leegyszerűsítetten fogalmazva: a korábban az egészségügyi krónikus betegellátás kapacitásai, valamint a krónikus ellátás iránti szükségletek és igények mintha egyaránt átterhelődtek volna a szociális szektorra, mely "trade-off” leképződik a szektorok foglalkoztatotti létszámának (előbb növekvő, majd visszarendeződve csökkenő) változására is. E váltás magyarázatát leginkább a költségvetési megfontolásokban találjuk, igen egyszerűen szólva, egy ember szociális gondozásának költsége kisebb, mintha az egészségügy látná el. Döntően azért, mert kevesebb és rosszabbul fizetett dolgozót lehet a szociális normatívából alkalmazni, mint az egészségügyi finanszírozásból a krónikus kórházi ágyak mellett. És nincsenek csodák: kisebb pénz, alacsonyabb szintű ellátás. Ennek az átrendeződésnek a tükrében még kevésbé tudjuk beazonosítani az immár jelentős ápolási teherrel sújtott szociális gondozási feladatok mibenlétét és a gondozottak közötti megoszlását. 13 A szociális gondozás és az egészségügyi ápolás összehangolása, integrációja mindenhol gond a világon. Az innovatív megoldásokról lásd: Bhattacharyya et al. 2020. 


\section{6. ábra. Az egészségügy tartós otthonápolásii kiadásai a GDP arányában}

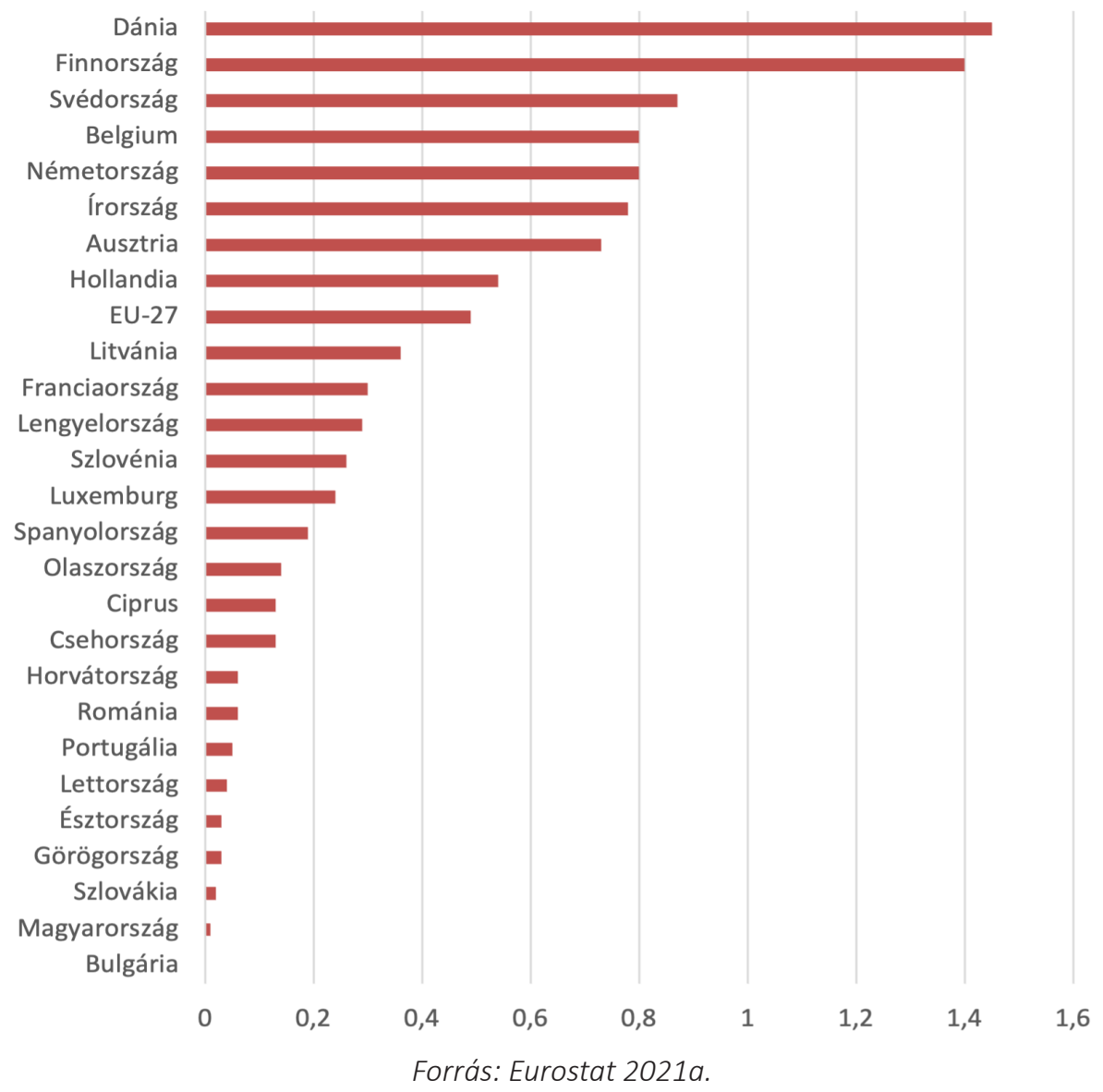

7. ábra. Az egészségügyben és a szociális ágazatban foglalkoztatottak létszámának változása 2009 és 2020 között

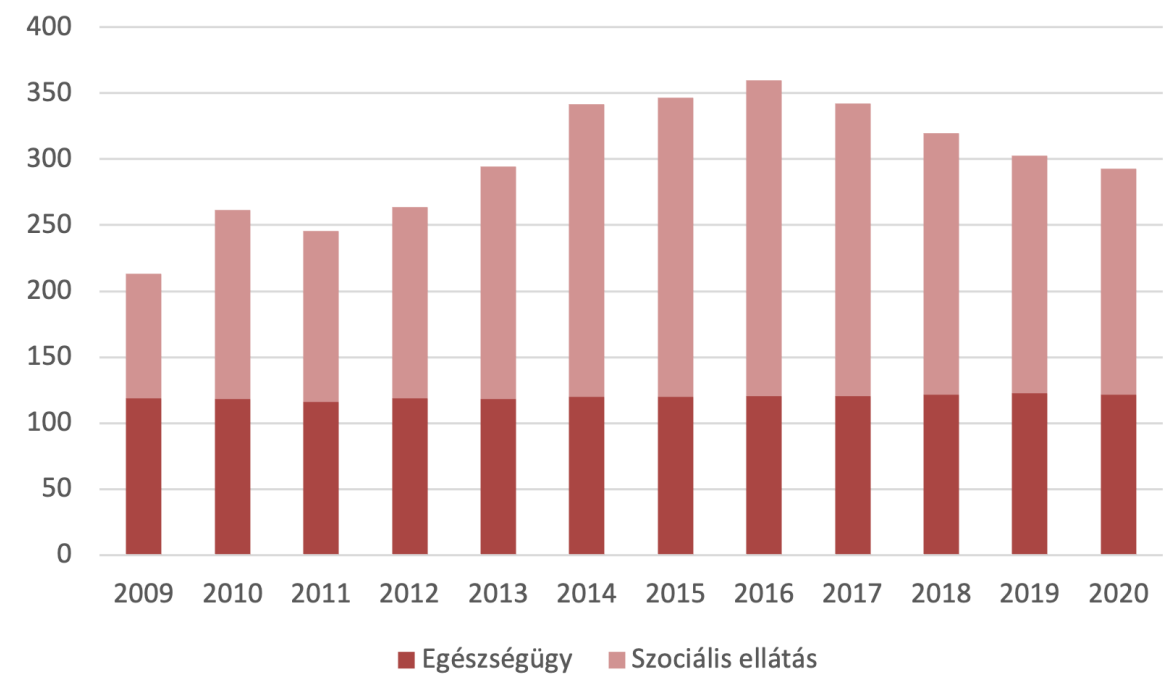

Forrás: KSH 2021c: KSH-STADAT 20.1.1.52

Nem-tudásunkat fokozza az, hogy a szociális intézmények jellemzően teljesen felkészületlenek a tartós ápolási (értsd: egészségügyi) feladatok ellátására. Egyszerű példákkal igazolható ez. A szociális intézmények többségében (a jogszabályokat kielégítő módon) a területi háziorvos szokta heti kétszer két órában biztosítani 
az orvosi ellátást. ${ }^{14}$ Képszerúen alátámasztva mondandómat, elegendő a gondozottak ágyainak elhelyezkedését megnézni. A szociális intézményekben az ágyak (a lakóházakhoz, lakásokhoz hasonlóan) a hosszabb oldalukkal illeszkednek a falhoz, míg az egészségügyi intézményekben ehhez képest „keresztbe állnak”, a rövidebb oldaluk, a fejrész van a falnál. Ennek elég egyszerű oka van: az egészségi ellátás során, különösen az ápolási feladatoknál gyakran két emberre van szükség a beteg mozgatásához, a „rajta” elvégzendő feladatokhoz, amelyeket gyakorlatilag lehetetlen ellátni, ha nem lehet két oldalról megközelíteni az ágyban fekvőt. A szociális intézményekben nem lehet két oldalról megközelíteni, mozgatni az ágyban fekvőt, így például megemelni sem nagyon lehet.

No de attól, hogy az ugyanolyan állapotú betegek „átterelődtek” a szociális ellátásba, ettől nem lett jobb az állapotuk, vagy kevesebb az ápolási, egészségügyi ellátásra irányuló szükségletük, amely ápolási szükségleteket a szociális intézmények sem létszámuk, sem a stáb felkészültsége, sem a dologi, eszközbeli feltételeik híján nem képesek kielégíteni. Ápolniuk (is) kell, pedig erre nem alkalmasak.

Erre csak a „gondozási” feladataik komoly átcsoportosításával képesek reagálni. Az intézményen belüli feladatátrendezésben kulcselem az, hogy ha bármilyen egészségügyi problémát észlelnek (amelyet tehát helyben nem tudnak megoldani), akkor azonnal riasztják a mentőket, hogy a gondozottat vigyék be a kórházba, értelemszerűen a problémának megfelelő akut kezelésre, akut férőhelyre. A szociális szektor folklórja szerint a stáb egy-egy (jellemzően magasabban képzett foglalkoztató vagy mentálhigiénés) nővérének a munkaidejét jelentős arányban leköti a mentődiszpécserekkel való folyamatos kapcsolattartás, hogy akárhogyan is, de érjék el náluk, hogy azonnal küldjék a kocsit, és lehetőleg ,jó helyre” szállítsák a lakójukat.

A krónikus osztályok férőhelyeinek, az egészségügy kereteiben végzett tartós gondozás pénzkímélési szándéktól vezérelt leépítése, beszúkítése nemcsak átrendezte (és még kiszámíthatatlanabbá tette) a gondozás feladatainak mibenlétét, a feladatok ellátását, de nyilvánvalóan rontotta a gondozás színvonalát is. Ezen túl, eközben nem biztos, hogy kellően takarékos és hatékony költségátrendezést jelent az egészségügyön belül sem az, ha a csökkentett krónikus ráfordításokat a megnövekedett riasztásokkal, a gyakori betegfelvételi és elbocsátási adminisztrációval, a gyakori felvételi kivizsgálásokkal és akut ellátásokkal igyekeznek „kiváltani”. A gondozás színvonalát és a gondozottak jól-létét is bizonyosan rontja az, ha a mentő folyamatosan „pendlizik” a szociális intézmény és a kórház akut osztályai között, és tán nem véletlen, hogy más országok inkább tartanak fenn krónikus ágyakat, hogy nem akut férőhelyeken kezelik az idősek felmerülő egészségi problémáit. ${ }^{15} \mathrm{Ez}$ a rendszer súlyosbítja az OECD által régóta kritizált problémákat abban, hogy az akut osztály a felvétel indikációjaként megnevezett „betegséget” kezeli csupán, és nem az ezernyi bajjal terhelt (hiszen idős...) beteget, amelyre a folyamatos krónikus ellátás során inkább van mód. Az átrendeződések még áttekinthetetlenebbé teszik az ellátandó gondozási feladatok tartalmát, hiszen a feladatot ellátó szociális intézmények még elvileg sem képesek a „rájuk szakadt” ápolási feladatokat ellátni.

Ami azért felsejlik, az az, hogy a jelenlegi szociális gondozási rendszerben, különösen a bentlakásos ellátásban többféle „gondozási ideál” egyszerre van jelen. Egyrészt fennmaradt az a szociális otthoni, „szegényházi” hagyomány, amely az életkörülmények, az anyagi biztonság és a magány problémáit akarja

14 A vonatkozó szabályozás (1/2000. (I. 7.) SzCsM rendelet, 2. számú melléklete) csak a 200 fónél több idős embert gondozó intézmények esetében írja elő 1 fő orvos foglalkoztatását, 100-200 fő között heti 6, 100 fő alatt heti 4 óra intézetben eltöltendő munkaidőt ír elő az intézménnyel szerződő orvos (leggyakrabban háziorvos) számára.

15 Közismert tény az, hogy Magyarországon sok a kórházi ágy és viszonylag alacsony az orvosi és ápolói szakszemélyzet létszáma. Nem ismerek adatokat, de valószínúsítem azt, hogy az idősek ápolási ellátása helyetti akut ágyakra való „pendliztetése” jelentősen hozzájárul a magas ágyszám fennmaradásához. 
orvosolni a gondozás eszközeivel. Másrészt számos idős embernek számos gondozási intézmény egyszerűen társaságot és közös programokat szolgáltat gondozásként. Harmadrészt, az egészségügyből átterhelt nyomás hatására, a korábbi, az eredeti „szociális gondozási” modellel szemben sokaknak az „elfekvők” funkcióját kell ellátni, és ápolással élhetővé tenni a leépülés, a halál előtti utolsó időszakot.

A fenti három különböző „gondozás” - minden hiányával együtt is - különféle módon finanszírozható a gondozás pénzbevételeiből (állami normativa és más támogatás, térítési dijj, egyszeri bekerülési díj). A „szegényház” szállás és koszt szolgáltatása nagyrészt kijön a normativából, a "társas panzió” wellnessszolgáltatásait magasabb térítési díjakból lehet finanszírozni; az "elfekvő” ápoló-gondozó otthon magas költségen múködik, de, bár cinikus ezt belátni, bevételeiben döntő tételt az egyszeri bekerülési díjak jelentenek - minél „gyorsabb a forgás”, minél hamarabb halnak meg a súlyos állapotban felvett gondozottak, annál jobban „megy az üzlet”. Mindezek az üzleti modellek jellemzően nem tisztán, hanem különféle arányban keveredve érvényesülnek az intézmények gazdálkodásában. A gazdálkodás átláthatóságát nagyban nehezíti az, hogy az egyre jelentősebb arányú egyházi intézmények nagyjából 75\%-nyi kiegészítő normatívát is kapnak a más tulajdonú intézményeknek is járó normativán felül. Összefoglalva: bárha nem is tudjuk, de megalapozottan sejtjük azt, hogy a gondozás tartalmában, a gondozási „koktélok” összerakásában igen jelentősek a szakmai, társadalmi, színvonalbeli eltérések, de e feltételezés „tudása” nyomán még kevésbé tudjuk, hogy hol mi is a feladat, ahogyan azt sem, hogy hol, miért, kit, miképp is kell/kellene gondozni, ellátni.

\section{A GONDOZÁSI PROBLÉMÁK URALKODÓ KONCEPTUÁLIS KERETE: A HIÁNY}

Az idősgondozás szakmai berkeiben a gondozásiszektor problémái közötta szóba kerülőgondok kimerülnek a legkülönfélébb hiányok felpanaszolásában. Nem kérdéses, hogy a hiányok léte, az „nem afféle vélemény, az tény, tény, tény"... A hiányok egyik legjobb mutatója a várólisták hossza: a bentlakásos intézményekbe várakozók száma majdnem a fele a férőhelyek számának. Hiányt jelez a betöltetlen gondozói álláshelyek növekvő száma, és különösen fájó a bérhiány, a szociális szektor dolgozóinak siralmas, relatív pozíciójában a népgazdasági ágak között a legalacsonyabb, reálértékéből egyre veszítő bérezése. Az alacsony bér a következménye a nominális értéken az elmúlt tíz évben változatlan normatíváknak, a reálértékéből veszítő intézményi közfinanszírozásnak. Mindezeket a hiányokat számszerűen adatolja Gyarmati Andrea (2019) tanulmánya. Ezen túl is „forrásértékü” az, ahogyan Gyarmati a hiány uralkodó narratíváját is rekonstruálja tanulmányaiban, így saját, a szociális területen dolgozókról szóló kutatásában pontosan dokumentálja azt, hogy a területen dolgozók számára mennyire központi kérdés az ágazat forrás-, bér- és létszámhiánya (Gyarmati 2021). S e hiányok az elmúlt évtizedben csak tovább gyarapodtak.

Kornai János (1981) az államszocialista gazdasági berendezkedésről szóló, a hiány általános, rendszerkonstituáló természetét fókuszba állító elemzéseiben a hiány sohasem úgy jelentkezik, hogy „van, amiből kevesebb van, de azért lényegében ugyanúgy működnek a dolgok", hanem úgy, hogy a hiány a rendszer alapvető múködési mechanizmusait, cél- és értékrendszereit is átformálja. A szocialista tervgazdaság hiánygazdaságát igencsak hasonlatosnak vélem a jelenkori intézményesült szociális gondozás hiánygazdaságához, annak minden anomáliájával, torzulásával: a dolgok nem úgy múködnek, ahogyan azoknak a leírt szabályok, a kimondott szavak alapján múködniük kellene. Ennek kimondása semmiképpen sem hízelgő, sőt, tán árulás is a gondozási rendszer irányítói, szolgáltatói számára, akiknek a rendszerbe lojálisan illeszkedve folyamatosan úgy kell viselkedniük és megnyilvánulniuk, mintha ők akkor is szabálykövetők lennének, ha az nem lehetséges. (Ennek egyfajta belátása az, amikor még ki sem mondódnak szabályok és szavak: például a gondozás tartalmáról.) 
Az égető hiányokat akárhogyan is, akármilyen kényszermegoldásokkal is, de muszáj pótolni. Ezek a barkácsolt pótmegoldások jellemzően rosszabb, gyakran pocsék minőségűek ahhoz képest, amit pótolni lennének hivatottak. Nemcsak rosszabb minőségúek, hanem gyakran a hiányokat kompenzáló területeken pazarlóak is, hiszen nem arra használják, amire azok eredetileg valók lennének. (Ilyenekre mutattam rá akkor, amikor azt jeleztem, hogy a magány nem túl szerencsés kezelési módja a bármiféle gondozás; vagy hogy a kórházi akut kezelésekre történő ki-be pendlizés rosszabb és költségesebb, mint az olcsóbb krónikus ágyak fenntartása - ahogyan ezt a világon máshol szokás.)

A szocialista hiánygazdaságra emlékeztető sajátosság az, hogy az intézményesült szociális gondozás is kitermeli a maga „második gazdaságát”, szürke és fekete foglalkoztatási formáit. Ezek jellemzően kényszermegoldások. Egy részük ma is a múltat megidézően megtürt-minta gondozásra szoruló idősek lakásában, bentlakásért és zsebbe fizetett bérért dolgozó „nénik” alkalmazása, de vannak formái, amelyek tiltottak és üldözöttek (mint például a panziók kereskedelmi múködéséhez hasonló nyugdíjasházak múködtetése). A szürke és fekete formák olykor kimondottan jó minőségű megoldást jelentenek, ám drágák és kiszámíthatatlanok, még a piaci fogyasztóvédelmi normákat sem lehet körükben érvényesíteni.

Ha a rendszeren belüli súrlódások fennakadásokat okoznak, ilyenkor „meg kell kenni” a súrlódó felületeket. Amikor az ember szóba hozza a szociális gondozáson belüli korrupció kérdését (pláne, hogy annyi bizonyított adatunk sincs erről, mint az orvosi hálapénzről), akkor ennek mértéke nem összevethető mindazzal, amit manapság korrupcióként máshol látunk. Az intézményvezetőknek és más döntéshozóknak a bekerülésért, a gondozóknak a számukra nem kötelező feladatellátásért zsebbe, „kenőpénzként” fizetnek a gondozási szektorban - ennek a paralizáló hatása akkor is összemérhető az orvosi hálapénzekkel, ha a szociális területen ezen kenőpénzek fizetése ritkább és kisebb összegű amazoknál. ${ }^{16}$

A hiánygazdaság megkerülhetetlen velejárója, sajátossága az, hogy a dolgok nem úgy múködnek, ahogyan azoknak (elvileg) múködniük kellene.

\section{AZ ÉRZÉKELT HIÁNYOK SZOKÁSOS NARRATÍV KÖVETKEZMÉNYE: áldozatiság ÉS PATERNALIZMUS}

\subsection{A narratíva fogalmának értelmezése}

Már eddig is használtam a narratíva manapság divatos és gyakran tisztázatlan fogalmát, most már tán ideje valamiféle definíciót, értelmezést is adnom hozzá. Bár magát a kifejezést nem használták, de a fogalom gyökerei Hegelig (1961 - eredeti: 1806), szociológiai előzményei Berger és Luckmann (1998 - eredeti: 1966) tudásszociológiájáig nyúlnak vissza. Ezek az előzmények arra hívják fel a figyelmet, hogy nem közvetlenül az „objektív” valóságról szólnak az ismereteink, nem a dolgok között látunk meg összefüggéseket, hanem azokról a fogalmakról (és az azok közötti összefüggésekről), amelyeket társadalmi konvenciók a jelenségek megnevezésére és értelmezésére használnak, amelyek révén megkonstruálják a valóságot. A már-már feledésbe merült koncepció - immár narratíva megnevezéssel - a 20. század végén a posztmodern antropológiának és történettudománynak köszönheti nemcsak újjáéledését, hanem általánosan (ámde gyakran tisztázatlanul) használt divattá válását, amelyet később átvett a pszichológia, a szociológia, a politológia, sőt az elmúlt években a közgazdaságtan is. E tudományágakban a narratíva a megélt és elmesélt történetek, emlékek, értelmezések létét valamiképpen a pozitivista módszerekkel feltárt „objektív valóság” logikai ellentéteként (vagy legalábbis

16 A bizonyíthatatlan szóbeszéd szerint gyakran nem is személynek, „zsebbe” fizetik e kenőpénzeket, hanem az intézmény „,bizonylatolt bevétele” helyett a fizetési kötelmek egy részét szatelit alapítványoknak, egyházi intézmények esetén a fenntartó egyháznak befizetett „támogatásként” teljesítik ezeket. 
azoktól független „kiegészítéseként”) értelmeződik. E narrativáknak immár nemcsak az „én”, nemcsak a társadalmi valóság megismerésében jelentős a szerepük, hanem - legalábbis sokak számára - az elmesélt és megkonstruált narratívák köré szerveződnek érdekközösségek, identitásközösségek, valamint (különösen populista) politikai pártok és mozgalmak.

Robert Shiller (2020) legújabb narratív közgazdaságtana értelmezésében a narratíva nem csupán a társadalmi és gazdasági valóság megkonstruálása, hanem értékelő és normatív tartalmakkal is bíró szöveg, amely eligazít abban, hogy mi a jó és mi a rossz, hogy mit kell tenni és mit nem szabad tenni - épp e normatív üzenetek követése által válnak válsággá bizonyos időszakban vírusszerűen elterjedő narratívák (Shiller 2020, Harari 2015). ${ }^{17}$ Én is ebben a kiterjesztett, valóságkonstruáló és normatív tartalmában használom a narratíva fogalmát - az idősgondozás narratíváira vonatkoztatva.

A narratívák sajátos kölcsönhatásban állnak a tényekkel. Egyrészt, a narrativák tényekre is alapulnak: nyilvánvalóan a "közös tudásként” ismert tényeket mesélik el a maguk szakmai zsargonjában, közösségi nyelvhasználatban, és ezeket a bensőségesen és gyakran belterjesen használt szavakat foglalják elmesélhető keretbe. Ami nincs, arról nincsenek szavak sem; amiről nincs vagy ignorált az ismeret, azt nem lehet narratív keretbe foglalni. Másfelől, a narratíva kijelöli a tények megismerése iránti kíváncsiság, a „belátott nem-tudás” köreit is: az az érdekes, az a kíváncsiságot gerjesztő, még nem-ismert, de megismerendő tény, ami a narratívát teljesebbé, megalapozottabbá képes tenni. A többi tény, az nincs vagy nem érdekes...

Hasonlók elmondhatók a narratívák normatív tartalmairól is. A használt nyelv, az adott nyelven elmesélhető tartalmak nemcsak a leírások és értelmezések lehetséges köreit jelölik ki, hanem legalábbis utalnak az elmondott sztorik előfeltevéseire is, és ugyancsak jelzik az elmesélt tartalmak normatív következményeit is mindarról, hogy ki és mi a jó és ki és mi a rossz; mi az, amit szabad és kell, és mi az, amit tilos. Ennek a szakmai/ hivatásrendi kohéziót teremtő, közösségi összetartozást erősítő narratívának a megtagadása, az némiképp a szakma, a közösség cserbenhagyása és megtagadása is. Ezt próbálták meg velem (nem durván, barátian, de) érzékeltetni azok a kollégáim, akik „árulásnak” titulálták azt, hogy elhagyom a szakma konvencionális narratív kereteit. Az „árulás” a felszínen az uralkodó narratíva, kevésbé annak leíró és értelmező, mint inkább kohéziót erősítő és normatív kereteitől való eltávolodás, ami mélyebben az adott közeg, a „brancs” cserbenhagyására, elárulására is utal.

De ha már felidéztem a narratíva - legalábbis a saját értelmezésem szerinti - előtörténetét, akkor afféle régimódias szociológusként érdemes felidéznem Bergerék (Berger-Luckmann 1998) következtetését is, akik számára e nyelvi fogalmi konstrukciók is gyakran többek a világ megkonstruálásánál, számukra a fogalmak gyakran fals mítoszokat (mai szavakkal: narrativákat és hiteket) is konstruálnak, amely mítoszok legalább annyira elleplezik a valóságot, mint amennyire kifejezik azt. Emiatt Bergerék szociológiai „programja”, követendő tudományetikai normája az a „kritikai” szociológia, amely a mítoszok fátyla alá is bekukkant, amelyik a leplek alatti valóságot is feltárja, ennyiben demisztifikálja a valóság mítoszait. Nos, e demisztifikáló programot is igyekszem régimódiasan követni akkor, amikor a fentebb értelmezett idősgondozási narratívákat elemzem.

17 Shillernek ezen, a valóság konstruálásán túlmutató, normativ és koordinatív funkciókkal felruházott narratívafogalma majdnem ugyanazt jelenti, mint Harari (2015) általánosító, az istenhitnél sokkal szélesebb körre értelmezett „vallás” fogalma. 


\subsection{Az áldozati narratíva}

Az áldozati narratívák alapvető közös sajátossága nem a kollektív identitásképző mondandójuk tartalma, hanem a narratívát beszélók közös áldozati pozíciója. Ez az áldozati pozícióból való történetmesélés nem az idősellátásban dolgozók kollektív tudatformálására jellemző sajátosság, ez a magyar történelmi és politikai identitások tán legalapvetőbb sajátossága. ${ }^{18}$

Ezen áldozati beszédmódnak, narratívának a legfontosabb sajátossága a „balsors, akit régen tép”, a hatalmak és ellenségek által leigázott, megnyomorított helyzet érzékeltetése, az ebből fakadó tehetetlenség megszenvedése. Az áldozat nem cselekvő „ágens”, hanem elszenvedője mások gonosz, alantas ármányainak és cselszövéseinek. Ugyanakkor a hazai identitások kifejtéséhez használatos áldozati narratívák nem a buta, átvert „lúzer” áldozati pozícióból szólnak, hanem jellemzően a mártíromság tragikus áldozati helyzetéből - amely azonnal valamiféle erkölcsi fensőbbségtudattal ruházza fel magát a beszélőt mint áldozatot (Balog 2015). Ez jellemzi a szociális szakmákban és különösen a szociális gondozási területen dolgozók szakmai identitását is. Amely sémában nem az amúgy tényleg létező túlszabályozott bürokratikus szabályozás játssza el az áldozattá tevő „gonosz hatalom” szerepét - a túlszabályozott bürokráciához való viszony inkább lojális, hiszen e bürokratikus elvárások teljesítése akkor is belátható és kielégíthető, sőt, emelkedett szolgálatként is megélhető, ha a gondozás szakmai tartalmai és normái tisztázatlanok. Az áldozati narratíva, a mártíromság erkölcsileg emelkedett, ámde fizikailag megnyomorított pozíciója a hiányból, a hiány rendszert konstituáló hatalmából eredeztethető. Abból, hogy a gondozási területen dolgozók kizsigerelt, kizsákmányolt áldozatként élik meg munkájukat, ebből a pozícióból mesélik el szakmai feladataikat és gondjaikat: nincs bér, nincs elég ember, egyre több a munka, és egyre kevesebb az elismerés mind a bürokratikus irányítók, mind az egyre zsörtölődőbb gondozottak részéről.

Ez a narratíva a problémák megoldásának irányát is evidensen kijelöli: a hiányokat pótolni, de legalábbis enyhíteni kell. „Árulásaim” újabb felvonásai e felfogáshoz köthetők: én nem gondolom azt, hogy egy alapjaiban félrecsúszott rendszer szisztematikus és strukturális problémái ennek az inadekvát szisztéma hiányainak kipótlásával megoldhatók lennének. Bármennyire is kiismert, megszokott, „belakott” e rendszer a benne dolgozók számára, pusztán a paraméterek megnövelése a rendszer paradigmáinak változtatása nélkül nem segíthet az alapvető problémák enyhítésében. ${ }^{19}$ Másrészt nem gondolom azt sem, hogy a gondozási szakma uralkodó narrativáját meghatározó áldozati pozíció, annak mártírként önfelmentett tehetetlensége konstruktív magatartás volna bármilyen probléma, akár a hiány „parametrikus” pótlásának orvoslására is. Változás csak akkor történhet, ha valakik, a rendszer szereplői változtatnak, ha a passzív és tehetetlenségre kárhoztatott áldozatiság helyett cselekvő ágensekként azonosítják magukat. Ezzel egyáltalán nem azt akarnám mondani, hogy a „hős”, vagy a „fejjel a falnak menés” stratégiáját várnám el, de azt igen, hogy cselekvő szereplőként legalább a falakig el kellene jutni. Hogy korábbi példámon illusztráljam: nem, bizonyosan nem lesz több pénz attól, ha a tartósan ágyban fekvők lábujjáról olykor levágják a megnőtt, meggyűlt körmöket. Azt azonban bizonyosan gondolom, hogy egyrészt ezt nem tiltja semmilyen szabály és finanszírozási korlát; másrészt, hogy

18 Ezt a témát járja körül a Korall folyóirat 2015-ben megjelent Áldozatnarratívák című tematikus száma, mely számból különösen Balog László Levente (2015) debreceni politológus kollégámnak a magyar nemzeti áldozatnarratíva változásaival foglalkozó kiváló cikkének szellemét követem itt.

19 Mivel a szemléletváltás vagy a reform fogalma meglehetősen kompromittálódott az elmúlt évtizedek politikai/közpolitikai gyakorlatában, ezért szívesen veszem át a társadalombiztosítási (nyugdíj és egészségügyi) szakemberek nyelvhasználatát, akik meg szokták különböztetni a pusztán a mértékeket átíró „parametrikus” változtatásokat a rendszer belső logikáját átrendező, tartalmi módosulásokat is jelentő „paradigmatikus” változásoktól. A paradigmatikus változtatás nem jelenti a korábbi rendszer felszámolását, de alkotóelemeinek újrarendezését, szerkezeti módosítását igen. 
ha ez a gondozás szempontjából fontos, netán másnál fontosabb feladat, mert így fel tud kelni legalább egy kis időre a gondozott anélkül, hogy összecsuklana a lába fájdalmaitól, akkor cselekvő ágensként ezt tán ki lehetne próbálni. Akár más, kevésbé fontos, rituális feladat elhanyagolása árán is.

\subsection{A paternalizmus sorsszerűségének narratívája}

Külföldi tanulmányútjaim során, amikor idősek gondozását végző intézményeket is meglátogattam, akkor nem az elhelyezés és a körülmények gazdagsága volt az, ami leginkább fejbekólintott. Volt egy azonnal szembeötlő körülmény, amely sokkolt, amelyet itthon nem ismertem: a parkoló. Amelyet nagyrészt nem a dolgozók autói foglaltak el (a dolgozók inkább biciklivel jártak) - hanem a gondozottaké. Ilyen nincsen! Ez sokáig nem fért a fejembe. Pedig de, a még vezetésre képes gondozottak olykor beültek öreg, még önálló életükben vett és megszokott autóikba, szóltak, hogy hova mennek és mikorra érnek vissza - majd úgy öregesen, óvatosan, lassan, a távirányítóikkal kinyitották a kaput és elhajtottak. Vásárolni, meglátogatni rokonaikat vagy barátaikat, vagy éppen egy múzeumba, moziba. ${ }^{20}$

Később a „gondozottak kocsija” problematikát a szociálpolitika, a szociális munka és gondozás emelkedettebb nyelvén is meg tudtam magamnak fogalmazni.

Általánosságban és első körben úgy tudnám ezt megmagyarázni, hogy a szociálpolitikában kulcskoncepcióvá vált „empowerment” fogalmát az angol anyanyelvű szociális szakma eléggé primitíven szokta értelmezni: mindenkinek addig van hatalma, ameddig választhat a lehetőségek között, ameddig dönthet a dolgairól. A választási és döntési lehetőségek biztosítása nem pazarló luxus, e feltétel teljesítése a szociális segítés „képessé tevő" missziójának fundamentuma. A tankönyvek szerint a szociális gondozás „segítést”, "rásegítést” jelent ahhoz, hogy a gondozott minél autonómabb módon, minél teljesebben képes legyen élni a saját, önrendelkező életét - és ami nem megy neki egyedül, amihez segítség kell, amiben akadályozva van, a saját döntése szerint fontos dolgainak megvalósításában, hát abban segíteni kell neki. Durván, együgyűen és primitíven: ez maga a gondozás. Amelynek része az, hogy abban is lehet és kell neki segíteni, hogy minél tovább, minél több ügyben maga választhasson és maga dönthessen. Hogy akar-e moziba menni, kivel, mit akar megnézni, és ha döntött, akkor könnyen, kényelmesen, minden felhajtás nélkül jusson el a moziba. Ebből a nézőpontból már nem a gondozottak autói tekinthetők sokkolónak, hanem a hazai idősgondozásnak az ügyfelek választásait negligáló, sorsszerűen paternalista értelmező kerete és normatív narratívája - nemcsak az idősek, hanem a fogyatékossággal élők vagy állami gondoskodásban élő gyerekek és fiatalok esetében is, sőt, a szociális munka szinte valamennyi területén.

A paternalizmus autoriter hatalomgyakorlást ír le, amelyet az különböztet meg más autoriter formáktól, hogy itt a kontrollok és direktívák előadásmódja valamiféle intim, családias, a maga módján még olykor szeretetteljesnek is túnő atyai-atyáskodó hatalomgyakorlás. Ne szépítsük: maga a gondozás, a gondoskodás már fogalmilag is paternalista. (Idegen nyelven is, a "care” is az angolul.) Eszembe nem jutna feltételezni e paternalizmusban semmiféle gonoszságot, rosszindulatot, a segítőkészség és „melegszívűség” hiányát az idősgondozás területén sem. Ha ezzel együtt a paternalista szellem „önkényuralmi” jellegének jelenlétét akarnám igazolni, akkor egyrészt a vonatkozó jogszabályok (mindenekelőtt az évente többször módosított, 1993. évi Szociális Törvény és a hozzá csatlakozó, még többször módosított 1/2000. rendelet) szövegeit elemezném.

20 Be kell valljam, nekem hasonló sokk volt az, hogy több városban a házi gondozás „,kiegészítő ellátása” a taxiutalvány. Bécsben ezt úgy magyarázták meg, hogy ha az elmúlt 50 évben a gondozott minden hónap második keddjén 4 órától együtt pletykálkodott egy kávéházban a barátnőivel, akkor fontos, hogy ezt addig folytathassa, addig élhesse ebben is a normális életét, ameddig csak lehet. 
Előbb igazolnám azt a sejtésemet, hogy a kötelmek jelentős hányada az intézményeknek az igazgatás felé megteendő kötelességét rögzíti és nem a gondozottak ellátására vonatkozó normákat. Majd megszámolnám azt, hogy az adminisztrativ, hivatalos kötelmeket kivéve, a követendő szabályok és előírások mekkora része ír elő a gondozóknak a gondozottak felé teljesítendő kötelmeket, és mekkora hányadban írja elő a gondozottak kötelességeit. Erős a gyanúm, hogy sokkal több szabály vonatkozik a gondozottakra, hogy garanciális, normatív erejú szabályok nem kötik a gondozók és intézményeik kötelmeit a gondozottak felé. Még súlyosabb aránytalanságokat sejtek abban, hogy a gondozási viszonyban melyik félnek milyen következményekkel kell számolnia akkor, ha a rájuk vonatkozó jogi szövegben rögzített kötelességeket nem teljesítik. A gondozottakra vonatkozó szabályok be nem tartása (házirend megsértése, térítési díj nem fizetése stb.) kodifikált szankciókat, akár a gondozásból való kizárást is maga után vonhatja - míg a gondozók számára (igaz, nem egyértelmú és normatív tartalommal, némi rugalmas dodonaisággal) megfogalmazott kötelmeknek nemhogy a szankcióit (pl. kártérítési kötelezettségét), de még a panaszok elbírálásának útját sem igazán szabályozza a jog.

Az interneten hozzáférhető tucatnyi intézményi házirend elolvasása nyomán úgy vélem, hogy a fenti aránytalanság még torzultabb a belső szabályok világában, mint a jogi anyagokban. ${ }^{21} \mathrm{~A}$ bentlakásos intézmények házirendjei elvétve és leginkább feltételes módban („nyújthat”, a „lehetőségek szerint” stb.), korlátozott terjedelemben (koszt, kvártély, gyógyszer, tisztaság stb.) fogalmaznak meg az intézmény által teljesítendő kötelmeket. Ezeken túl a gondozottak számára kötelezően előírt diktátumok gyűjteményei, amely diktátumok megsértésének szankcióit is taglalják a házirendek. E diktátumok és jogkorlátozások indokoltak lehetnek döntésképtelen, cselekvőképtelen gondozottak esetében, ${ }^{22}$ ám mivel az idősek gondozási intézményeiben kicsi a gyámoltak aránya, így összességében nehezen lenne megmagyarázható e kötelezések köre. Merthogy a házirendek szerint a gondozottak akkor kelnek, akkor esznek, akkor és úgy töltik „szabadidejüket”, azokkal a speciális indokokkal akkor és úgy hagyhatják el az intézményt, ahogyan azt a házirend előírja számukra.

Ha valaki a gondozás igénybevételét elfogadja - akkor azzal lényegében lemond jogairól, szabadságáról, azzal magára nézvést elfogadja a gondozási intézmények uralmát. ${ }^{23}$ Ennek talán az egyik eklatáns példája a térítési díjak esete. A 3. táblázat Gyarmati (2019) adatai alapján a leggyakrabban előforduló, a szabályozás által elkülönített szociális gondozási szolgáltatások térítési díjainak mértékét foglalja össze.

\section{3. táblázat. Térítési díjak maximális mértéke a Szociális Törvény alapján}

\begin{tabular}{|l|l|}
\hline Idősellátási szolgáltatás & Térítési díj mértéke \\
\hline Falu- és tanyagondnoki szolgálat & Nincs \\
\hline Szociális étkeztetés & A sajátjogú jövedelem max. 30\%-a \\
\hline Házi segítségnyújtás & A sajátjogú jövedelem max. 25\%-a \\
\hline Nappali ellátás (Idősek klubja) & A sajátjogú jövedelem max. 15\%-a \\
\hline Átmeneti elhelyezés, gondozóház & A sajátjogú jövedelem max. 60\%-a \\
\hline Idősek otthona (tartós elhelyezés) & $\begin{array}{l}\text { A sajátjogú jövedelem max. 80\%-a, valamint az intézmény fenntartója által } \\
\text { meghatározott belépési hozzájárulás (nincs törvényi limit) }\end{array}$ \\
\hline
\end{tabular}

Forrás: Szociális Törvény, 1/2000 SZCSM rendelet, idézi: Gyarmati 2019

21 Megdöbbentő, hogy a ma elérhető belső működési rendek és házirendek mennyire nem változtak azóta, hogy Horváth Ágota (1988) a '80-as évek közepén vizsgálta e kérdést, hogy ebben a tekintetben mennyire „megállt az idő", hogy mennyire időtállók egykori kollégám kiváló elemzései.

22 A jogkorlátozást, jogi értelemben vett cselekvőképtelenséget a gyámság jogintézménye írja körül. Manapság a fogyatékosellátások kapcsán előtérbe került elemzések szerint, indokolatlan kiterjedtséggel és mélységgel. A problémát a Hoffman István által vezetett „Nagykorúak cselekvőképességének korlátozása” című kutatás vizsgálta (Hoffmann et al. 2020).

23 A gondozás hatalmi aspektusairól Michel Foucault $(1990,2004)$ elméletei az irányadók. 
Nem is az a térítési díjak legfőbb furcsasága, hogy a közszolgáltatások körében leginkább, legmagasabb összegekkel a szociális szektorban van jelen ez a fizetési kötelezettség, hanem az, hogy e díjak nem piaci vásárlás kereteiben a szolgáltatás értékarányos ellentételezései, a fizetéssel nem a „vevő” határozza meg, hogy az adott áron mit vesz meg. Ez inkább az adókra emlékeztető fizetési kötelemre hasonlít, amit vállalnia kell annak, aki aláveti magát a gondozási hatalomnak. A díjak mértékének különbségei nem igazán a szolgáltatások értékének eltéréseit fejezik ki: nem a „fogyasztott” szolgáltatások mennyiségéhez és minőségéhez igazodnak, a térítési díj nem „piaci ár”. A térítési díj mértéke a gondozott jövedelme arányában kerül megállapításra, a gondozott a jövedelmének adott arányáról fizetési kötelemként lemond a gondozási intézmény javára. Az adókhoz hasonlóan, a be nem fizetett térítési díjak behajthatók, a gondozott tulajdonára terhelhetők.

A hazai szociális szakma érzékeli azt, hogy paternalisztikus szakmai berendezkedése idejétmúlt, poros eszméken alapszik az „enpowerment” új irányaihoz képest. Mégis ezt az idejétmúlt, a szocializmus időszakából folyamatosan ismerős eszmét és berendezkedést kritika nélkül tudomásul veszi - a hiányra való hivatkozással. A szolgáltató paternalista hatalmával szemben a fogyasztó döntési, választási lehetősége a gondozott nagyobb hatalmát is jelenti. A paternalista szemlélet fennmaradásához nagyban hozzájárul az a racionálisnak tűnő narratíva: hogy hiányok mellett a választás lehetősége pazarló luxus, hogy a párhuzamos, választható lehetőségek felkínálására a hiányok szorításában nincsen sem lehetőség, sem szükség. Emiatt nem reális alternatíva új módszerek és eszközök kipróbálása sem, hiszen azok is csak a kínálatot bővítő luxust jelentenék. Nem is kell, nem is érdemes a régről felgyülemlett problémák alternatív megoldásaival sem küzdeni: örüljünk, ha bárhogyan, akárhogyan is, de „eldöcög a szekér”. A létező gondozási rezsimben a mindenütt jelenlevő hiány nemcsak nyűg és gond, hanem a régi, begyöpösödött gyakorlatok kiváltását, de még csak korrekcióját is nélkülözhetővé tevő narratív hivatkozási alap. (Amely paternalista szakmai apológiával én speciel nem értek egyet, de ez is csak egy újabb „árulás”.)

\section{NEM FELTÉTLENÜL A MÚLT PROBLÉMÁINAK MEGOLDÁSÁRA KIÉPÜLT MAI RENDSZER HIÁNYAINAK A PÓTLÁSA A MEGOLDÁS...}

A hiány és a paternalizmus fentebb vázolt uralkodó narratívája „nem lát ki” a rendszer jelenlegi kereteiből. Nem látja általában az idősek helyzetét, akiknek nagy része semmilyen segítséget nem kap gondozásként, akik a rendszeren belülről nézve „valahogyan csak elvannak”. E semmit sem kapó többség létének felvetése tán „árulásom” leginkább elmarasztalt esete, hisz nélkülük is égető a hiány... Még mielőtt bárki legyintene arra, hogy én itt az állami pénzből finanszírozott, intézményi szabályozás hatálya alá tartozó gondozás adatait nézem csupán, amely értelemszerúen nem vonatkozik azokra, akiknek akadályozottságát, életének menedzselésében mutatkozó nehézségeit úgyis megoldja a család, a környezet - az téved.

A European Social Survey adatai szerint (Verbakel et al. 2017, idézi: Gyarmati 2019) az Unióban Magyarországon a legalacsonyabb azoknak az aránya, akik családtagjukat, rokonukat, közeli ismerősüket informálisan gondozzák -azaz, nálunk a legalacsonyabb azoknak az idős embereknek az aránya, akik bármiféle informális (családi) gondozásban részesülnek. Meghaladná e dolgozat lehetőségeit ezen adatok értelmezése, ${ }^{24}$ így az informális gondozás alacsony szintjének a kicsi lakásméretekkel való összefüggése (nem lehet odaköltözni a gondozandóhoz, még csak ott aludni sem feltétlenül), vagy annak mérlegelése, hogy a családtagok, rokonok által fizetetlenül végzett, a nemzetközi összehasonlító elemzésekben informális gondozásként tárgyalt

24 Az informális gondozás kérdésében szintén csekély az ismeretünk, pedig a nemzetközi adatok alapján érdekes kérdéseket lehetne felvetni arról, hogy az intenzív (heti 11 órát meghaladó) gondozásban kisebb az elmaradásunk, hogy az informális gondozásban jelentős a női többlet, vagy hogy a diplomások kevésbé gondozzák idős hozzátartozóikat, mint az alacsonyabb végzettségüek. 
gyakorlatot mennyire fedi át vagy mennyire váltja ki, helyettesíti a bejárónők és az ott alvó „nénik” vélhetően magas fekete (informális?) foglalkoztatása.

Ami azonban bizonyosnak látszik, az az, hogy új eszközök és források bevonása nélkül nem találhatunk megoldást az idősödési válságnak arra a tényezőjére, hogy a mai idősek túlnyomó többsége semmilyen segítséget sem kap. A számuk pedig nő: a ma 70 év alatti „Ratkósok” be fognak öregedni a segítségre, gondozásra szoruló nagyon idősek közé.

Itt nincs lehetőségem valamiféle konzisztens társadalmi stratégia kidolgozásának felvázolására arról, hogy milyen új forrásokkal és eljárásokkal lehetne javítani a ma is létező idősellátási formák igazságosságán és hatékonyságán, vagy hogy milyen új komponensek bővíthetnék az idősellátás forrásait és kapacitásait. Leginkább és legfeljebb csupán néhány ötletet tudok „feldobni” itt e kérdés kapcsán.

Eléggé nyilvánvaló lépés lenne a mostani, a gondozási rendszer mindenütt felbukkanó hiányaiból fakadó pazarlásokcsökkentése. Ennek egyik eleme lehetne az, hogy ha az idősekéletvezetési gondjait pénzzel is enyhíteni lehet, ott nem érdemes az igen magas foglalkoztatási költségú, intenzív munkaerő-felhasználású gondozással orvosolni a gondokat. Olcsóbb és tán célravezetőbb is lenne az anyagi gondjaiktól szorongó, háztartásukban egyedül élő idős embereknek lakhatási támogatást nyújtani és nem intézményben elhelyezni őket. ${ }^{25}$ Ugyancsak sokat segíthetne az önálló otthoni életet könnyebbé és kényelmesebbé tevő lakásfelszerelési eszközöknek (például a zuhany falára szerelhető, lehajtható műanyagszékek, amelyeken ülve is lehet „szédülésmentesen” zuhanyozni) vagy olcsó és célszerűen „lebutított” technikai eszközöknek (nem okos mobiltelefonok, alacsony teljesítményű, de videókapcsolatra alkalmas számítógépek, „lebutított”, a hangerő szabályozásán kívül csak a beállított csatornák váltására képes TV-távirányítók stb.) beszerzését és díját a gyógyászati segédeszközökhöz hasonló konstrukcióban államilag támogatni.

A takarékosságot és ezzel együtt a kapacitások több ember számára való elérhetőségét javítaná a „túlgondozási” hatások ${ }^{26}$ visszafogása: az, ha a gondozási feladatok specifikálva lennének és nem a „mindent vagy semmit" opciók között lehetne választani. Az ügyfelek választási lehetősége minimális szinten ma is megvalósul a heti néhány órás házi gondozás esetében, de alig érhető tetten a költségesebb bentlakásos gondozást nyújtó intézményekben. (Nem lehet például csak panziós jellegű, társaságban lakás „védett és biztonságos" lehetőségét választani, csak együtt a komplett gondozással). Az ügyfelek választási lehetőségének bővítése amúgy is az ügyfelek elégedettségét, ezen keresztül a szolgáltatás minőségét, annak érzetét javítaná.

A gondozási feladatok specifikálása is javítaná nemcsak a takarékosságot, hanem a gondozás színvonalát is. Szakmai sztenderdek rögzíthetnék azt, hogy milyen egészségügyi és élethelyzetben mit is kell elvégezni gondozásként, és a részletezett feladatok közül a gondozott is kiválasztaná azt, amire szüksége/igénye van. Ilyen specifikációk alapján lehetne észszerűen rendezni a krónikus egészségügyi ellátás és a szociális gondozás közötti munkamegosztást; sőt, kizárólag az efféle specifikáció alapján lehetne összehangolni, esetleg integrálni is a két terület feladatait (Bhattacharyya et al. 2020).

$25 \mathrm{Az}$ intézményi elhelyezést többnyire maga az elhelyezést kérő (olykor a családtagjai, igen ritkán a háziorvosa) kezdeményezi, de a kérelmet részben az intézményeket fenntartó állami és nem állami szervek, döntő súllyal pedig maguk a szolgáltató intézmények bírálják el, azaz: gyakorlatilag ők döntenek arról, hogy kit vesznek gondozásba.

26 A gondozás olykori „over-protective” tulajdonságának a hazai szakirodalomban nem túl gyakran használt szó szerinti fordítása a „túlgondozás”. Azt fejezi ki, hogy a gondozás olykor olyan tartalmakat is magába foglal, amire a gondozottnak semmi szüksége nincsen, képes lenne azt maga is megoldani. Ez a túlgondozás nem csupán pazarlás, de a gondozás szakmai tartalmának minőségrontását is jelenti: ha az idős emberek kevésbé látják el a maguk körüli teendőiket annál, mint amennyire erre képesek, akkor ez a leépülésüket gyorsítja. 
A ma is létező szolgáltatási tartalmak rugalmasabbá tételéhez jelentős deregulázásra is szükség lenne. Illúzió azt hinni, hogy központosított, bürokratikus direktívákban lehet részleteiben szabályozni azt, hogy ki mit kaphat (kinek mit kell kapnia). Kompetens szakembereknek kellene tekinteni a gondozási intézmények, szervezetek vezetőit, akiket nem „rövid pórázon kell rángatni”, hanem - az utólagos, a közpénz költése esetén kötelező, a döntéseket rekonstruálni, ellenőrizni képes, elszámolható és transzparens bizonylatolás, dokumentálási és könyvelési kötelezettségek mellett - felelős döntésekre kell felhatalmazni és késztetni annak érdekében, hogy a rájuk bízott erőforrásokat jól, takarékosan, igazságosan osszák be és jól gazdálkodjanak a rájuk bízott lehetőségekkel.

Ehhez persze nyilvánvalóan szükség lenne a dokumentálási tartalmak újragondolására, az adminisztráció észszerúsítésére is. „Könyvelni” kellene a jelenlegi inputok mellett azt, hogy kiket is gondoznak, milyen kiválasztási és elbírálási szempontok szerint gondozzák a szolgáltatásaik igénybevevőit, fogyasztóit, de az inputokon túl az elvégzett munkát is (output), és az elért eredményeket, hatásokat is (outcome). Az önálló döntéseket is jelentő, a helyzet tárgyszerű átlátására építo „menedzselés” nem biztos, hogy kevesebb adminisztrációs teherrel jár a bürokratikus papírmunkához képest - de bizonyosan javítani képes a gondozás hatékonyságán és igazságos elosztásán, valamint módot ad a felmerülő múködési problémák feltárására, megbeszélésére, korrigálására és végső soron persze akár a mulasztások szankcionálására is.

Pusztán a jelenlegi kapacitások rugalmasabb felhasználása, még a pénzbeli és (dologi, nem szolgáltatásjellegű) természetbeni támogatások bővítésével sem képes a ma semmiféle támogatást nem kapó 90\%-nyi 65 év feletti igényeinek megfelelő bővülést elérni. De bizonyosan nem csupán jelentős kapacitásbővítést, hanem az ügyfelek választási lehetőségeinek bővülését is jelentené a piaci és civil szereplők intenzívebb részvétele a gondozásban. Ennek minimális adminisztratív előfeltétele a múködési engedélyeztetés és az állami támogatás kettéválasztása. Ma ugyanis az a helyzet, hogy aki rendelkezik múködési engedéllyel, az automatikusan az állami támogatás igénybevételére is jogosult. A (szabályozott) piac bővülése automatikusan a választás lehetőségeinek, a fogyasztó hatalmának a bővülésével is járna, ám ehhez a jelenlegitől eltérő szellemű igazgatási adminisztrációra is szükség lenne. A gondozási piac nyilvánvalóan nem jelentheti a „lovak közé dobott gyeplőt”, ennek megteremtéséhez a piacszabályozás és a fogyasztóvédelem legalább olyan szintű megteremtésére van szükség, mint ami, mondjuk a kereskedelem vagy a vendéglátás piacszabályozása területén létezik. Sőt, mivel a gondozás területén a fogyasztók kiszolgáltatottsága, a „piaci aszimmetria” erősebb, mint a legtöbb piaci szolgáltatási területen, annál még szofisztikáltabb piacszabályozásra és felügyeletre is szükség lehet.

A piaci szabályozási környezetben természetesen mód nyílhatna nemcsak a jelenlegi „gondozási feketepiac” kifehérítésére, hanem legális bővítésére, sőt akár adókedvezményekkel, részleges állami támogatására is. Feltehetően számos önkéntes és civil segítőt mobilizálhatna pusztán az, ha a mai önkéntesség szabályai szerint a segítők indokolt költségei (pl. utazási) adómentesen megtéríthetőek lennének.

Végül a gondozásban aktív társadalmi szereplők körének bővítése együtt járhatna a laikus, professzionális normákkal nem körülbástyázott, akár szervezeti keretek nélküli, „szomszédsági” segítségnyújtás bővítésére is. Végtére is ahhoz, hogy valaki rányissa az idős emberekre az ajtót egy köszönésre, egy beszélgetésre, esetleg még egy tányér levest is áthozva "kóstolónak” - ehhez nem kell se szervezet, se szakmai felkészültség, csak egy kis odafigyelés. Ilyen „szomszédsági”, laikus segítségnyújtás elszórtan bár, de megjelent különféle közösségfejlesztési projektekben, gyakran aktívak ebben az egyházak (külön tanulmányt érdemelne, de különösen a „szektajellegü”, hivatalos formában akár el sem ismert kisegyházak) - ám „lokális” példájuk egyelőre, legalábbis társadalmi léptékben nem érzékelhető. 


\section{AMIRŐL MEG AZT SEM TUDJUK, HOGY MIT NEM TUDUNK...}

Fenti, némiképp technokrata és közpolitikai jellegű ötletelésemben egy súlyos csalást követtem el. Úgy tettem, mintha evidensen létező társadalmi és közpolitikai cél lenne az, hogy az önmaguk ellátására nem vagy csak korlátozottan, nehézségekkel képes időseket „gondozni kell”. Ám a „segítő magánattitűd” akkor sem jelent társadalmi vagy politikai attitűdöt, ha sokan, akár a társadalom többsége is így gondolkodik. Sőt, a társadalmi és politikai gondolkodásmód a régmúlt időkig visszanyúlóan ennek inkább az ellenkezője.

A premodern társadalmaknak igencsak embertelen emberképük volt az idősekről, arról a kevésről, akik egyáltalán megérték az időskort. Jobb esetben tudomást sem vettek arról, hogy közösségük idős tagjai a korral leépülnek, képességeik csökkennek, és ugyanolyan aktivitást vártak el tőlük, mint mindenki mástól, a fiatalabbaktól. Rosszabb esetben, és különösen, ha a közösség éhezésben, nyomorban szenvedett - akkor igencsak durva és kegyetlen bánásmód jutott az időseknek. William Graham Sumner népszokásokról szóló könyve Magzatelhajtás, csecsemőgyilkosság, az öregek megölése címú fejezetében (1978:455-489) számos példát hoz arra, hogy a primitív népek egyszerűen meggyilkolták a terhessé vált, haszontalan öregeket. És nem sokkal finomabb megoldás az sem, ahogyan Sántha Ferenc (a 20. század második felében írt) Sokan voltunk címú novellájában az idős nagyapát öngyilkosságra késztetik, hogy „felmenjen a Büdösbe” (Sántha1974).

Bár a primitív barbárság mint megengedett társadalmi viszony később enyhült az idősekkel szemben, de az idősekhez társadalmi és politikai szinten „haszontalan koloncként” való viszonyulás tovább él: a modernitásban is fennmaradt, így leképződött a szociológiai és statisztikai gondolatvilág előfeltevéseire is. A szociológia rétegződés- és struktúraelméleteiben az emberek társadalmi státuszát, jogállását, rangját és értékét a társadalmi munkamegosztásban elfoglalt hely határozza meg - és így, akik koruk, egészségi állapotuk miatt kiesnek a munkamegosztás struktúrájából, azok ezzel státuszukat is elveszítik. Az idősekből így a statisztika kategóriái szerint haszontalan, csak gondot jelentő „eltartott” lesz. Akkor is, ha az eltartottságba a haszontalanságot és értéktelenséget csak hallgatólag értik bele. A barbár kegyetlenséggel szemben az eltartottság mégiscsak kifejez valamiféle társadalmi helyet: az eltartott nyugdíjat és idősellátást kap, paternalistán „el van tartva”, akkor is gondoskodunk róluk, ha cselekvő szerepet nem tulajdonítunk nekik.

Ebben az eltartotti koncepcionális keretben az jelent gondot, ha valaki sokáig él, ha az „eltartásuk” nemcsak azért költségesebb, mert nagyon idősen drága ápolásra és gondozásra szorulnak, hanem egyszerűen azért is, mert sokáig élnek, hosszú időn keresztül el kell tartani őket. Akik hamar meghalnak, másoknál fiatalabb korban élik fel egészségüket, ebben az értelemben fiatalabban öregszenek, és akik „megteszik azt a szívességet” a társadalomnak, hogy az idősödés életkorhoz kötött társadalmi konvenciói szerint nem kell őket eltartani emiatt, azok a korai haláluk ellenére sem jelentenek a társadalom érzékelése szerinti „idősödési” gondot. Mintha ők nem is öregednének meg a haláluk előtt (pláne, ha ők képzetlenek, alacsony a státuszuk, gyenge a politikai hangjuk és érdekérvényesítő képességük)... Mintha nem a korai halál jelentene gondot - hanem a tisztes időskorban eljövő halál, amely elérkezéséig hosszú ideig kell gondozni az idős embereket.

Két ügyben bírnak az idősek a státuszvesztésük ellenére bármiféle társadalmi és gazdasági jelentőséggel. Egyrészt akkor, amikor a gondoskodó nyugdíjrendszereknek a létszámnövekedéssel együtt hála, de növekvő vásárlóerőt, fogyasztói hatalmat tulajdonítunk nekik. Ez a vásárlóerő különféle jelentőséggel bír különböző szektorokban, például a turizmuson belül a szezonon kívüli, vagy a gyógyturizmus nem létezne akkor, ha az idősek nem utaznának, legalább akkor, amikor az olcsóbb. A másik tényező szintén összefügg az idősek létszámának és lakosságon belüli arányának növekedésével, ez pedig a növekvő szavazati befolyásuk, „választói hatalmuk” sokak szerint túl nagy hatalmuk. Emiatt az idősek ellátásának, gondozásának a kérdése akkor válik társadalmi és 
politikai üggyé, amikor választások következnek, amikor számít és kell a szavazatuk. Ehhez a szavazatnyeréshez ígéretek, gyakran ígérgetések kellenek. A választások után a nyugdíj és az idősgondozás, éppúgy, mint maguk az idősek is, leginkább csak gond és teher, gyakorta csak a költségvetési pénzek elvonásának és megszorításának „terepévé" rendeződik vissza.

Szóval az egész témát a leginkább alapjaiban érintő kérdés az, hogy miért is volna szükségük a haszonelvűségre épülő modernitás társadalmainak az idősekre. Miért is akarjuk/akarnánk gondozni az időseket? Miért is ne akarnánk e gondot a lehető legolcsóbban és legegyszerúbben, a társadalmi hasznok legkisebb veszteségeivel megúszni? Miért is kellene azon problémázni, hogy miképpen lehetne az idősek léte legitim, értékeket hordozó, fontos tartozéka a társadalmi létnek? - Be kell valljam, hogy ezekre a kérdésekre nem tudom a választ - még a kérdéseket sem tudom jól feltenni. Mintha maga az idősödés ténye lenne az, ami, ha nem is konkrét tartalmaiban, de legalább a társadalmi többség szorongásaiban valamiféle választ követelne: No, de mi lesz, ha mint mindenki más, én is megöregszem? (Davis-Scherz 2020, 2021). ${ }^{27}$ Ez a szorongás azonban nem jutott el addig a józan és racionális kérdésfeltevésig, hogy mi is lenne majd jó segítség, jó támogatás nekem akkor, ha én is rozzant, törékeny, önmagam ellátására képtelen idős leszek. A szorongásoknak ma egyetlen konklúziója van: így vagy úgy, de rossz lesz. Amíg nem tudunk társadalmi értékeket tulajdonítani az időseknek, addig nem is lesz jobb nekik. Addig pedig komoly ok van arra, hogy csak azon tudjunk szorongani, hogy egyszer majd nekünk is rossz lesz.

27 Az idősödés jelenkori, így részben a pandémiával is összefüggő szociális, orvosi és etikai dilemmáit boncolgatja a Davis és Scherz szerkesztésében megjelent kötet, illetve a szerkesztők nézeteit foglalja össze cikkük (2021) 


\section{HIVATKOZÁSOK}

Balog L.L. (2015) A magyar nemzeti áldozatnarratíva változásai. Korall, 16(59), 36-53.

Berger, P.L. - Luckmann, T. (1998) A valóság társadalmi felépitése - Tudásszociológiai értekezés. Budapest: Jószöveg Műhely Könyvkiadó.

Bhattacharyya, O. - Shaw, J. - Sinha, S. - Gordon, D. - Shahid, S. - Wodchis, W.P. - Anderson, G. (2020) Innovative Integrated Health And Social Care Programs in Eleven High-Income Countries. Health Affairs 39(4), 689-696. https://doi.org/10.1377/hlthaff.2019.00826

Davis, J.E. - Scherz, P. (2021) Recovering Old Age. The New Atlantis, 63, 52-62. https://www.thenewatlantis.com/publications/ recovering-old-age

Davis, J.E. - Scherz, P. (szerk.) (2020) The Evening of Life - The Challenges of Aging and Dying Well. Notre Dame: Notre Dame University Press.

Foucault, M. (1990) Felügyelet és büntetés. Budapest: Gondolat Kiadó.

Foucault, M. (2004) A bolondság története a klasszicizmus korában. Budapest: Atlantisz Könyvkiadó.

Gil-Lacruz, M. - Gil-Lacruz, A. (2010) Health Perception and Health Care Access: Sex Differences in Behaviors and Attitudes. The American Journal of Economics and Sociology, 69(2), 783-801.

Gyarmati A. (2019) Idősödés, idősellátás Magyarországon - Helyzetkép és problémák. Budapest: Fridrich Ebert Stiftung.

Gyarmati A. (2021) A szociális ágazatban dolgozók munkakörülményeinek, járványhelyzettel, szakszervezetekkel kapcsolatos véleményének felmérése. Kutatási jelentés. Elérhető: https://www.researchgate.net/publication/349519530_A_szocialis_ agazatban_dolgozok_munkakorulmenyei_jarvanykezeles_erdekervenyesites [Letöltve: 2021-10-08].

Harari, Y. N. (2015) Sapiens - Az emberiség rövid története. Budapest: Animus Könyvek.

Hegel, G.W.F. (1961) A szellem fenomenológiája. Budapest: Akadémiai Kiadó.

Hoffman I. - Gulya F. - Tőkei B. (2020) A nagykorúak cselekvőképességének korlátozásának - hazai jogi keretek és az azzal kapcsolatos föbb adatok. Elérhető: https://edit.elte.hu/xmlui/static/pdfjs/web/viewer.html?file=https://edit.elte.hu/ xmlui/bitstream/handle/10831/55428/hoffman_gulya_tokey_nagykoruak_cselekvokepessege_korlatozasa_keretek. pdf?sequence=1\&amp;isAllowed=y [Letöltve: 2021-10-08].

Horváth Á. (1988) A szociális otthon. Budapest: MTA Szociológiai Kutatóintézete.

Kornai J. (1981) A hiány. Budapest: Közgazdasági és Jogi Kiadó.

Kovács K. - Bálint L. (2018) Halandóság. In Monostori J. - Őri P.- Spéder Zs. (szerk.) Demográfiai portré 2018. Budapest: KSH NKI, 147-176.

Krémer B. (2013a) Idős? Gondozás? Miról beszélünk? Esély, 3, 66-112.

Krémer B. (2013b) Köszönet a hozzászólóknak. Esély, 4, 119-125.

Krémer B. (2013c) Miért is olyan félelmetes a társadalmak számára az, ha az emberek tovább élnek. Az időskori egyenlőtlenségekről és a legnagyobb egyenlőtlenségi tényezőről: a halálról... Szociológiai Szemle, 23(3): 51-83.

Krémer B. (2015) Mi is a kétségbeejtő abban, hogy tovább élünk? Avagy az idősödési válság és a halál egyenlőtlenségei. Budapest: Napvilág Kiadó.

Lo, R.Y (2020) Uncertainty and health literacy in dementia care. Tzu Chi Medical Journal, 32, 14-8. doi: 10.4103/tcmj.tcmj_116_19

MNB (2017) A háztartási szektor pénzügyi megtakarításai mikro- és makrostatisztikai adatok alapján. Budapest: MNB. https://www. mnb.hu/letoltes/haztartasok-hun-0531.pdf

Monostori J. - Grestits G. (2018) Idősödés. In Monostori J. - Őri P. - Spéder Zs. (szerk.) Demográfiai portré 2018. Budapest: KSH NKI, 127-145.

Oksavik, J.D. - Solbjør, M. - Kirchhoff, R. - Raknes Sogstad, M.K. (2021) Games of uncertainty: the participation of older patients with multimorbidity in care planning meetings - a qualitative study. BMC Geriatrics, 21, 242.

https://doi.org/10.1186/s12877-021-02184-z

Oksuzyan, A. - Dańko, M.J. - Caputo, J. - Jasilionis, D. - Shkolnikov, V.M. (2019) Is the story about sensitive women and stoic men true? Gender differences in health after adjustment for reporting behavior. Social Science \& Medicine, 228, 41-50. https://doi.org/10.1016/j.socscimed.2019.03.002

Sántha, F. (1974) Isten a szekéren. Budapest: Szépirodalmi.

Shiller, R.J. (2020) Narratív közgazdaságtan - Hogyan hatnak a vírus módjára terjedő történetek a gazdaságra? Budapest: HVG Könyvek. 
Sumner, W.G. (1978) Népszokások - Szokások, erkölcsök, viselkedésmódok szociológiai jelentősége. Budapest: Gondolat Kiadó.

Verbakel,E. - Tamlagsrønning, S. - Winstone, L. - Fjær, E.I. - Eikemo, T.A. (2017) Informal care in Europe: findings from the European Social Survey (2014) special module on the social determinants of health. European Journal of Public Health, 27(1), 9095. https://doi.org/10.1093/eurpub/ckw229

\section{INTERNETEN ELÉRHETŐ ADATBÁZISOKBÓL LETÖLTÖTT ADATOK}

Eurostat (2020a) Life expectancy by age, sex and educational attainment level, Elérhető: http://appsso.eurostat.ec.europa.eu/nui/ show.do?dataset=demo_mlexpecedu\&lang=en [Letöltve: 2021-05-19].

Eurostat (2020b), Employment and Social Inclusion Indicators, Health and Long-Term Care, Elérhető: https://ec.europa.eu/eurostat/ web/employment-and-social-inclusion-indicators/social-protection-and-inclusion/health-long-term-care [Letöltve: 2021-0521].

Eurostat (2021a), Health care expenditure by function. Elérhető: https://appsso.eurostat.ec.europa.eu/nui/show.do?dataset=hlth_ sha11_hc\&lang=en [Letöltve: 2021-05-19].

Eurostat (2021b), Health Care Expenditure by Function. Elérhető: http://appsso.eurostat.ec.europa.eu/ [Letöltve: 2021-05-16].

KSH (2020) Eurostat, statikus táblák. Elérhető: ksh.hu/docs/hun/eurostat_tablak/index.html) Akut kórházi ágyak száma (2006-2017)Százezer lakosra, https://www.ksh.hu/docs/hun/eurostat_tablak/tabl/tps00168.htm [Letöltve: 2021-05-16].

KSH (2021a) STADAT 4.1.1.18. Kórházak. Elérhető: http://www.ksh.hu/stadat_files/ege/hu/ege0018.html [Letöltve: 2021-05-16].

KSH (2021b) KSH-STADAT 22.1.1.3 Népesség korév és nem szerint, január 1. Elérhető: https://www.ksh.hu/stadat_files/nep/hu/ nep0003.html [Letöltve: 2021-09-10].

KSH (2021c) KSH-STADAT 20.1.1.52. Az alkalmazásban állók száma nemzetgazdasági áganként Elérhető: https://www.ksh.hu/stadat_ files/mun/hu/mun0052.html [Letöltve: 2021-09-10].

OECD (2018) Health at a Glance: Europe 2018. Elérhető: https://www.oecd-ilibrary.org/social-issues-migration-health/health-ata-glance-europe-2018/public-spending-on-long-term-care-as-a-percentage-of-gdp-2016-to-2070-ageing-working-groupreference-scenario_health_glance_eur-2018-graph165-en [Letöltve: 2021-05-22].

OECD (2019) Time Use. Elérhető: https://stats.oecd.org/Index.aspx?DataSetCode=TIME_USE [Letöltve: 2021-05-19].

OECD (2020a) Health Data. Elérhető: https://data.oecd.org/health.htm [Letöltve: 2021-05-22].

OECD (2020b) Health Statistics. Elérhető: https://www.oecd-ilibrary.org/social-issues-migration-health/data/oecd-health-statistics_ health-data-en [Letöltve: 2021-05-22].

OECD (2020c): Focus on...Spending on long term care. Elérhető: https://www.oecd.org/health/health-systems/Spending-on-longterm-care-Brief-November-2020.pdf [Letöltve: 2021-05-19].

OECD (2021a): Life expectancy at 65. Elérhető: https://data.oecd.org/healthstat/life-expectancy-at-65.htm\#indicator-chart [Letöltve: 2021-05-22].

OECD (2021b) Life expectancy at birth. Elérhető:https://data.oecd.org/healthstat/life-expectancy-at-birth.htm [Letöltve: 2021-05-23].

OECD (2021c) Long-Term Care Resources and Utilisation Long-term care recipients. Elérhető:https://stats.oecd.org/viewhtml. aspx?datasetcode=HEALTH_LTCR\&lang=en [Letöltve: 2021-05-22].

OECD (2021d) Public spending on long-term care as a percentage of GDP, 2016 to 2070 - Ageing Working Group reference scenario. Elérhető: https://www.oecd-ilibrary.org/social-issues-migration-health/health-at-a-glance-europe-2018/public-spending-onlong-term-care-as-a-percentage-of-gdp-2016-to-2070-ageing-working-group-reference-scenario_health_glance_eur-2018graph165-en [Letöltve: 2021-05-24].

United Nations Population Division, World Population Prospects 2019. Elérhető: https://population.un.org/wpp/Download/Standard/ Population/ [Letöltve: 2021-05-21].

WorldBank (2019) (szerk: Kaneda, T. -- Greenbaum, Ch. - Patierno, K.) World Population Data Sheet. Washington, DC: Population Reference Bureau. Elérhető: https://www.prb.org/2019-world-population-data-sheet/ [Letöltve: 2021-05-19] 